\title{
Home Bias and International Risk Sharing: Twin Puzzles Separated at Birth*
}

\author{
Bent E. Sørensen \\ University of Houston and CEPR
}

Oved Yosha

Tel Aviv University

\author{
Yi-Tsung $\mathrm{Wu}$ \\ Binghamton University \\ Yu Zhu \\ Binghamton University
}

This version: July 2006

\begin{abstract}
We show that international home bias in debt and equity holdings has declined during the late 1990s at the same time as international risk sharing has increased. Using panel data estimations, we demonstrate that less home bias is associated with more international risk sharing. Alternatively, we show that the higher the level of foreign assets to Gross Domestic Product, the more risk sharing is obtained. This indicates that lack of risk sharing and international financial integration are closely related empirical phenomena.
\end{abstract}

JEL Classification: F36

Keywords: consumption smoothing, income smoothing, international portfolio diversification.

${ }^{*}$ For helpful comments we thank Mathias Hoffmann, David Papell, Roberto de Santis, René Stulz, and Linda Tesar as well as participants at meetings of the Western Economic Association, the Allied Social Science Meetings in Atlanta and Philadelphia, and seminars at the University of Houston, the University of Dortmund, and the Oved Yosha memorial conference in Tel Aviv. Oved Yosha died from cancer on August 7, 2003. His tragic early death is a great loss to us all. 


\section{Introduction}

Hedging of risk is central to economic and financial theory but macroeconomists and financial economists tend to have different notions of full hedging. The economics literature departs from the benchmark model of perfect markets, which in a setting of endowment economies under standard assumption implies that consumption growth rates are equalized ("perfect risk sharing") while the financial literature typically departs from the benchmark of the international Capital Asset Pricing Model (CAPM) which under standard assumption predicts that countries hold identical international portfolios of risky assets. In the present article, we measure the deviation from the perfect risk sharing allocation (or, equivalently, the amount of risk sharing obtained) and we measure the deviation from the international CAPM allocation ("home bias"). Then, we examine if large home bias is associated with low risk sharing for a sample of OECD countries 1993-2003.

The macroeconomic literature on risk sharing and the financial literature on home bias have generally been quite separate which explains the subtitle of this article, although Lewis (1999) considers both literatures in a very readable survey article. Home bias and risk sharing may be manifestations of the same underlying behavior: if agents diversify their portfolios internationally they will likely obtain smoother income streams as domestic shocks partially will be offset by foreign asset income and, of course, smoother income is likely to imply smoother consumption. Consider the (simplified) identity:

$$
G N P=G D P+r_{D} A_{D}-r_{F} A_{F},
$$

where GNP is Gross National Product, GDP is Gross Domestic Product, $A_{F}$ is the stock of domestic assets owned by foreign residents, $r_{F}$ is the rate of return on these assets, and $A_{D}$ and $r_{D}$ are domestically owned foreign assets and the return on those, respectively. If the term $r_{D} A_{D}-r_{F} A_{F}$ is not perfectly correlated with 
GDP, the GNP of a country may be less variable than it would be in the absence of international assets. ${ }^{1}$

Home bias and risk sharing need not be close twins. As explained by Lewis (1999), there are several circumstances where home bias may not lead to lack of risk sharing. In particular, even if agents do not smooth income through cross-ownership of assets they can smooth consumption through borrowing and lending. Such behavior may be optimal, by the logic of permanent income theory, if income shocks are temporary; ${ }^{2}$ however, aggregate shocks seem to be better characterized as permanent. Also, full international diversification of equity portfolios may not lead to smooth income if overall equity investment is small relative to GDP or if equity provides little hedging of returns to human capital (wage income) - see Baxter and Jermann (1997). Most countries hold fairly small amounts of net foreign assets. In the context of equation (1), this implies approximately $A_{F}=A_{D}$ and if returns on foreign and domestic assets are highly correlated it is immediately obvious that GNP will differ little from GDP. Such could be the case if foreign investment is not primarily determined by hedging considerations.

This paper empirically provides the missing link between the home bias and risk sharing literatures by demonstrating that disappearing home bias and increasing risk sharing indeed move hand-in-hand. We use a panel of countries from the Organization of Economic Cooperation and Development (OECD) and show that when home bias declines, risk sharing increases. In terms of equation (1), a larger domestic stock of foreign assets $\left(A_{D}\right)$ (variously transformed) predicts higher risk sharing.

We use two alternative measures of risk sharing. Ultimately, economic agents care about consumption and the macroeconomic literature focusses on testing for perfect consumption risk sharing or measuring how far consumption growth

\footnotetext{
${ }^{1}$ The term $r_{D} A_{D}-r_{F} A_{F}$ typically makes up the larger part of "net factor income from abroad" in the national accounts.

${ }^{2}$ See Baxter and Crucini (1993) and Heaton and Lucas (1996).
} 
deviates from the perfect market allocation. However, consumption data are affected by taste shocks (broadly defined) and because net foreign capital income, such as dividends and interest from foreign assets, directly affect GNP, we also consider "income"-based risk sharing based on GNP in the hope of getting a better "signal-to-noise" ratio. On the other hand, consumption data may be preferable if the return to foreign assets are dominated by yet-to-be-realized capital gains which will affect consumption but not be recorded in net foreign asset income (or, it may be recorded at points in time that, for our purpose, are incorrect).

Our measure of income-based risk sharing is the value of $\kappa$ estimated from the panel-data regression

$$
\Delta \log \mathrm{GNP}_{i t}-\Delta \log \mathrm{GNP}_{t}=\text { constant }+\kappa\left(\Delta \log \mathrm{GDP}_{i t}-\Delta \log \mathrm{GDP}_{t}\right)+\epsilon_{i t} .
$$

Here GNP $i t$ and GDP $i t$ are country $i$ 's year $t$ per capita GNP and GDP, respectively, and $\mathrm{GNP}_{t}$ and $\mathrm{GDP}_{t}$ are the year $t$ per capita aggregate GNP and GDP for the OECD - see below for more precise definitions. If income is fully diversified the growth rate of each country's income equals that of aggregate (OECD-wide) income implying that the left-hand side of the equation will be zero and $\kappa$ will equal zero. If there is no risk sharing state-level income will equal state-level GDP (and aggregate income will equal aggregate GDP) and $\kappa$ will equal unity. In general, the larger the value of $\kappa$, the less risk sharing and we will use the value of $1-\kappa$ as measure of income risk sharing (or "income smoothing").

Our main results, however, are obtained from similar regressions where $\kappa$ is allowed to be a function of time and of home-bias (or the ratio of foreign assets to GDP). We find that risk sharing increases when home bias decreases. Similarly, using regressions similar to equation (1) we find that consumption risk sharing (or "consumption smoothing") on average has increased over time and, according to our empirical analysis, this increase is fully due to countries with less home bias obtaining more consumption smoothing. 
Previously, very little systematic empirical evidence has been brought to bear on this issue and, surprisingly, the empirical research so far does not strongly support the notion that less home bias is associated with higher international risk sharing. Lane (2001) studies this question and concludes that "positive gross international investment positions in general are not associated with incomesmoothing at business-cycle frequencies." But in a study of the Irish case, Lane (2000) finds that international equity positions do contribute to Ireland's risk sharing with other European countries. However, international security holdings have been rapidly increasing throughout the 1990s and, therefore, any impact on risk sharing should now be easier to detect.

In Section 2, we describe data sources and take a first look at asset holdings and risk sharing. In Section 3, we discuss home bias in more detail. We construct indices of home bias in equity and bond holdings and show that home bias have declined rapidly from 1993 to 2003. In Section 4, we discuss risk sharing in more detail. We calculate measures of risk sharing and show that international risk sharing has increased significantly in the 1990s. In Section 5, we examine the central empirical question of the article and ask if countries with less home bias obtain better income and consumption smoothing. We also examine if risk sharing is correlated with foreign assets (equity, debt, or foreign direct investment) or with foreign liabilities. Section 6 concludes the paper.

\section{Data}

We obtain annual foreign equity, debt, and foreign direct investment assets and liability data from Lane and Milesi-Ferretti (2006) (LMF). ${ }^{3}$ Stock market capitalization for a country is measured as the value of publicly traded equity listed on the stock market exchange(s) and the data are from Standard \& Poor's "Global

\footnotetext{
${ }^{3} \mathrm{~A}$ previous version of this paper used asset data from the IMF's Coordinated Portfolio Investment Surveys for 1997 and 2001. The results using those data were similar, although somewhat less robust reflecting that the present data are superior for the present purpose.
} 
Stock Markets Factbook" 2003, 2004, and 2005. We define "world market capitalization" as the sum of the stock market capitalizations of the developed and emerging stock markets listed in this source. We measure the size of the total equity portfolio of country $i$ as market capitalization of country $i$ plus foreign equity held by country $i$ minus the amount of country is equity held by foreigners. We take that latter number to be the sum of equity holdings in country $i$ owned by other countries in the LMF data.

We obtain data for the capitalization of debt markets from the Bank for International Settlements (BIS) Quarterly Review. We measure the size of a country's total market capitalization as outstanding domestic debt securities plus outstanding international debt securities. Foreign debt holdings and the countrys debt held by foreigners are from LMF while domestic and international debt securities outstanding are from the BIS. The size of the total debt portfolio of a country is calculated in the same fashion as the equity portfolio- the size of the total bond portfolio of a country is outstanding domestic debt securities plus foreign debt held by the country. We define "world market capitalization" as the sum of market capitalizations in the BIS.

Data for GDP, GNP, Population, Final Consumption, and Consumer Prices are from the OECD National Accounts 1970-2004. We do not use quantity indices for real GDP because we are interested in measuring how much the purchasing value of GDP gets insured internationally. We compute Purchasing Power Parity (PPP) adjusted aggregate (OECD-wide) GDP growth rates as follows. We deflate GDP of each country with the price index normalized to 1 in 1995 and translate to PPP-adjusted U.S. dollar values using 1995 U.S. dollar exchange rates (taken from the OECD National Accounts). These PPP-adjusted series are then aggregated to OECD-wide real GDP. GNP and Consumption are aggregated similarly.

In Table 1, we display holdings of foreign equity, debt, and foreign direct investment for 1993 and 2003 for the 24 OECD countries that comprise our sam- 
ple: Australia, Austria, Belgium, Canada, Denmark, Finland, France, Germany, Greece, Iceland, Ireland, Italy, Japan, Mexico, Netherlands, New Zealand, Norway, Portugal, Spain, Sweden, Switzerland, Turkey, United Kingdom, and the United States. In order to get a first impression of the potential macroeconomic importance, we normalize the foreign asset holdings of each country by its nominal GDP.

It is immediately clear that holdings of foreign assets have increased steeply from 1993 to 2003. Table 1 also reveals large differences across countries. For example, in 2003 Ireland held large amounts of foreign equity and debt with levels that far exceeded the level of Irish GDP. Ireland is somewhat of an outlier with larger holdings of foreign stocks and bonds relative to GDP than other countries; the next highest ratio of foreign equity to GDP is found for Switzerland with a ratio of 91 percent for equity and 328 percent for debt. At the other end of the spectrum, Turkey held foreign equity and debt in amounts less than 1 percent of Turkey's GDP while Japan held an amount of foreign equity equal to only 6 percent of GDP in 2003. One cannot help but wonder if Japan might have softened the blow of her long recession in the 1990s through further international diversification.

Foreign debt holdings are on average four times larger than foreign equity holdings although that ratio is much larger for Japan and lower for the United States. Foreign direct investment assets are on average slightly larger than portfolio equity holdings although Ireland holds significantly more portfolio equity and the UK holds relatively more foreign direct investment.

Liability holdings are quite similar to asset holdings although debtor nations, such as Australia, holds less assets than liabilities and vice versa for creditor nations, such as Switzerland.

The striking aspect of the numbers in Table 1 is the steep increase in foreign asset holdings from 1993 to 2003. To take an example, foreign equity holdings in Italy increased from 3 percent of GDP to 23 percent of GDP during this time 
span. While this might partly be due to a run-up in the value of foreign equity holdings, we observe the same pattern, although slightly less pronounced, for international holdings of debt and foreign direct investment - these categories more or less trebled relative to GDP for many countries.

The large variation across time and across countries delivers the variation that will allow us to test econometrically if home bias (international asset holdings) and risk sharing are related.

\section{International portfolio holdings and home bias}

\subsection{Theoretical background and previous literature}

Most recent research build on the mean-variance framework which posits that agents prefer high mean returns and low variance. In the absence of "frictions" and in the presence of a safe asset, the simplest CAPM-model holds. This model predicts that all investors hold a mix of the safe asset and the "market portfolio." (The literature mainly focuses on equity.) Alternatively, if agents have similar mean-variance utility trade-offs, all agents will hold the same world portfolio even in the absence of a safe asset. Neither set of assumptions is likely to be literally true, but the model has been a long-term work-horse in finance and provides a useful yardstick which has been used extensively in the literature.

Many applications of the CAPM model consider only U.S. equity indices, although Grubel (1968) pointed out forty odd years ago that international diversification can improve the mean-variance trade-off compared to holding a purely domestic portfolio. This seems to be a robust result: Lewis (1999) shows that this conclusion hasn't changed since then. However, countries typically hold the vast majority of their asset portfolio in domestic assets. This phenomenon is referred to as international home bias and documented by, e.g., French and Poterba (1991) and Tesar and Werner (1995). Parts of the literature on home bias focus on the amount of international asset holdings relative to benchmarks, 
such as the CAPM, and parts of the literature focus on returns to domestic versus more internationally diversified portfolios. In this article, we calculate home bias for equity and bonds while we do not consider returns. Before we define our precise measure of home bias, we will briefly survey some of the literature that aims at justifying theoretically the deviations from the international CAPM model observed in the data. Our empirical work is not dependent on which, if any, of these models holds true but the patterns we observe in the data may be interpreted in light of the insights from the literature.

Hedging of currency risk is a likely "suspect" in explaining deviations from the simplest CAPM model: the international version of the CAPM alluded to above implicitly assumes Purchasing Power Parity (PPP). In the absence of PPP, investors may optimally want to deviate from the aggregate world portfolio in order to hedge currency risk as detailed by Adler and Dumas (1983). However, Cooper and Kaplanis (1994) find that inflation hedging is not a likely explanation of home bias.

The existence of transactions costs associated with international asset trading is another likely candidate for explaining home bias. Domowitz, Glen, and Madhavan (2001) find that such costs are important, especially for emerging markets, although Cooper and Kaplanis (1994) find that with reasonable level of risk aversion, observable costs of holding foreign equity do not explain home bias in equity holdings. Tesar and Werner (1995) find that foreign equity is being turned over at a higher rate than domestic equity which is hard to reconcile with higher trading costs of foreign equity. Warnock (2002) argues that the measurement of turnover rates may be problematic although he, similarly, finds no direct effect of transactions costs on home bias, while Mann and Meade (2002) find statistically significant but small effects of (directly measured) transactions costs. Overall, it seems that transactions costs may have a small effect on home bias but cannot fully explain home bias on their own .

A third class of potential explanations of home bias centers on the role of 
information. Specifically, lack of information adding to the riskiness of foreign investment - see for example Gehrig (1993). Kang and Stulz (1997) demonstrate that Japanese investors overinvest in large firms, consistent with a role for informational costs and, in a recent article, Ahearne, Griever, and Warnock (2004) show that patterns of U.S. equity investments in foreign countries are consistent with informational asymmetries. ${ }^{4}$ Portes and Rey (2005) find that informational variables, such as telephone traffic, help explain home bias, consistent with a role for informational asymmetry. Coval and Moskowitz (1999) and Huberman (2001) suggest that informational asymmetry may even explain intranational investment patterns within United States.

Further suggested explanations for home bias include Obstfeld and Rogoff (2000), who suggest that home bias is caused by cost of trading goods internationally while Strong and Xu (2003) find that fund managers are relatively more optimistic about high future returns for their home markets. Moral hazard and enforcement issues can also affect international investment. Moral hazard in international markets often takes the form of sovereign risk (Eaton and Gersovitz 1981, Bulow and Rogoff 1989). Within the OECD, defaults on government bonds are unlikely events but tax and other policy variables can be tailored to fall disproportionally on foreign investors.

Finally, some authors raise the possibility that the extent of home bias is less than what meets the eye at first. For example, Dahlquist, Pinkowitz, Stulz, and Williamson (2003) argue that the simplest CAPM model that uses stock market capitalizations for calculating the world benchmark fails to take into account that closely held stocks typically are not available (or not attractive) to foreigners - a fact which partly explains deviations from the international CAPM. Alternatively, one might conjecture that international diversification might be obtained indirectly through multinational corporations but Jacquillat and Solnik

\footnotetext{
${ }^{4}$ Consistent with this, Edison and Warnock (2004) find, examining security-level holdings of emerging market equities by U.S. investors, that equities that are cross-listed on a U.S. exchange are incorporated into U.S. portfolios with full international CAPM weights.
} 
(1978) demonstrate that this channel is not able to provide much diversification. ${ }^{5}$

For further discussion of potential explanations for equity home bias, see Lewis (1999) — who finds none of them particularly convincing — and Karolyi and Stulz (2003). These surveys should also be consulted for more extensive references to the literature.

We will not test any explanations of home bias, but the strong decline in equity and debt home bias during the late 1990s is consistent with trading costs and informational asymmetries declining due to falling costs of trading and information. While currency risk has been eliminated for mutual investments among members of the European Monetary Union (EMU), countries - such as Norwaythat are not members of any currency union also display rapidly declining home bias. This makes it less likely that hedging of currency risk is the main reason for home bias.

\subsection{Measuring home bias}

Based on the international version of the CAPM, we define a measure "Equity Home Bias" such that (Equity) Home Bias is 0 if the share of country $i$ 's equity investment that is invested domestically equals the share of country $i$ 's equity market in the total world equity market - in other words, a country will have Home Bias equal to 0 if it shows no preference for equity issued domestically. We normalize Equity Home Bias to be 1 if a country is 100 percent invested domestically. More precisely, we define Equity Home Bias of country $i=1$ minus (share of country $i$ 's holdings of foreign equity in country $i$ 's total equity portfolio / the share of foreign equity in the world portfolio).

While the financial literature typically focuses on equity markets, international diversification need not be limited to corporate equity. Investments can

\footnotetext{
${ }^{5}$ This is still an active research area: Cai and Warnock (2004) show that allowing for foreign operations of U.S. listed multinationals doesn't explain home bias although it makes the apparent home bias smaller. Rowland and Tesar (1998), looking at returns, find weak evidence that investing in multinationals helps provide diversification, but that further gains can be obtained from holding international assets.
} 
be diversified through foreign direct investment, real estate, bank deposits, etc. ${ }^{6}$ In this paper, we calculate indices for home bias in debt markets along with home bias in equity markets and leave the study of home bias in other markets for future research. We define "Debt Home Bias" in the same way as Equity Home Bias - substituting "debt" for "equity" in the definition. Burger and Warnock (2004) consider home bias in bond holdings. They find that U.S. investors could have obtained better risk-return trade-offs by investing more in foreign bonds during the 1994-2003 period as long as currency risk were hedged. Burger and Warnock (2004) also find that international bond holdings clearly are much lower than a CAPM benchmark might suggest. It appears that the home bias puzzle only gets deeper if bond holdings are considered simultaneously with equity.

Table 1 revealed that foreign equity holdings have increased relative to GDP in every single country. However, during this period equity market capitalizations have increased rapidly in most countries, as can be seen from the left-most two columns in Table 2, so this doesn't necessarily imply that Equity Home Bias has decreased. Similarly, from the right-most two columns of Table 2, it is clear that the value of outstanding debt has increased for most countries from 1993 to 2003. For a few countries, like Portugal, the value of bonds outstanding has increased rapidly but, in general, debt markets grew somewhat slower than equity markets during this period.

In Table 3, the left-most columns show the percentage share of foreign equity in the aggregate portfolio of each country. It is clear that foreign equity holdings have increased faster than the overall domestically held portfolios. For most countries - see the middle columns of Table 3-domestic market capitalization has been a fairly constant share of world market capitalization. Notable exceptions are Japan, whose equity market capitalization dropped from 21.40 percent to 9.49 percent of world market capitalization, and Finland whose relative equity market capitalizations trebled. The right-most columns of Table 3 display

\footnotetext{
${ }^{6}$ Buch, Driscoll, and Ostergaard (2005) show that banks over-invest domestically relative to simple benchmarks.
} 
numbers for Equity Home Bias in 1993 and 2003 as well as the change over this period. In 2003 two countries had Equity Home Bias less than 0.5, namely the Netherlands and Austria. Equity Home Bias in both of these countries has declined rapidly, for example, in Austria Equity Home Bias has declined steeply from 0.87 to 0.39 from 1993 to 2003. Equity Home Bias has indeed declined for all countries except Greece.

In Table 4, we display - see columns labeled (1) - shares of foreign debt in domestic debt portfolios, (2) the size of national debt markets relative to the world-wide debt market, and (3) Debt Home Bias. The numbers are, overall, fairly similar to those for Equity Home Bias. For example, average Debt (Equity) Home Bias is 0.63 (0.83) in 1993 and 0.52 (0.67) in 2003. Debt Home Bias has declined for most countries, with the exceptions being Japan, Mexico, and Turkey. All countries have positive Debt Home Bias but Ireland has the lowest at only 0.06 in 2003 while Iceland has a very high Debt Home Bias of 0.83 in 2003 .

Figure 1 display the average level of equity and debt home bias for each year of our sample. It is obvious from the graphs that home bias on average is steadily declining and we will next turn to the question of whether this has been associated with increasing international risk sharing.

\section{International risk sharing}

\subsection{Theoretical background and previous literature}

The macroeconomic literature focuses on aggregate consumption and income patterns rather than financial returns. We will refer to the case where consumption growth rates in all countries are identical as "full (or perfect) consumption risk sharing (or consumption smoothing)." This condition will hold for endowment economies if consumers have identical Constant Relative Risk Aversion utility functions and access to a complete set of Arrow-Debreu markets. In this 
case, the market equilibrium will be one where each country consumes a constant country-specific fraction of world output (which in this setting is also world consumption). ${ }^{7}$ This is a market equilibrium in which countries with relatively stable output get allocated a larger average share of world output as compensation for accepting a higher variance of consumption.

The simple characterization of the equilibrium allocation makes it obvious that the existence of a full set of Arrow-securities is not necessary for the implementation of the equilibrium. Countries can sell the right to their total output at competitive prices and invest the proceeds in claims to the output of other countries in such a way that all countries hold a similar world portfolio whose yield is proportional to world output. Assets linked to the GDP of individual countries do not trade on stock exchanges (although Shiller (1993) has suggested the creation of such assets as a way to hedge macro risk). However, it is feasible that such assets can be well mimicked by investment in international equity and debt securities. Common stocks, which have state dependent returns, may seem the most natural instrument for mimicking GDP-linked returns but the ex post returns on fixed rate bond investments are also de facto state dependent. Bankruptcy is the most obvious form of state dependency of bond returns but international debt is often renegotiated - see Obstfeld and Rogoff (1996) for a textbook discussion or Lewis (1999).

Similarly, we use the term "full (or perfect) income risk sharing (or income smoothing)" to describe the situation where the growth rate of GNP is identical in all countries. In this case, we would expect consumption growth rates to also be similar (at least if taste shocks are not too large).

Actual consumption growth rates (for OECD countries) are very far from being perfectly correlated. Backus, Kehoe, and Kydland (1992) find that the correlation of country-level consumption with world-consumption is less than one and even less correlated than output growth rates! This finding is referred

\footnotetext{
${ }^{7}$ Obstfeld and Rogoff (1996) provide a clear textbook derivation of the result that the rate of consumption growth should be identical across consumers and, therefore, also across countries.
} 
to as the international risk sharing puzzle ("lack of risk sharing"). Economists have also tested for perfect risk sharing using regressions: for example, Obstfeld (1994b) regresses country-level consumption growth on world consumption growth and own-country income growth. Under perfect risk sharing the coefficient to world consumption should be one and that to own-country income should be zero, but that prediction squares badly with the data. ${ }^{8}$ Sørensen and Yosha (1998) perform regressions that are similar to those of Mace (1991) and Obstfeld (1994b) but nested within a decomposition of the cross-sectional variance of country-level Gross Domestic Product (GDP). Their analysis shows that GNP is typically not smoothed at all before 1990 while consumption is far from perfectly smoothed. ${ }^{9}$

The textbook endowment economy is obviously ignoring many aspects of real economies and research has centered on several extensions of the basic model. Backus, Kydland, and Kehoe (1992) allow for optimal capital investment and leisure choice in a Real Business Cycle (RBC) model with productivity shocks. Their model predicts that consumption movement are less than perfectly correlated across countries but the predicted correlation is still high and much higher than what they find in the data. Stockman and Tesar (1995) show that taste shocks in consumption potentially explain why international consumption correlations are low but one still would like to know what "taste shocks" captures more precisely.

Part of the explanation for low international consumption correlations likely has to do with the existence of goods that are not tradeable across borders. Lewis (1996) shows, in a regression framework, that non-tradeables potentially explain the lack of risk sharing under a set of assumptions about functional forms etc. Likely non-tradeables are part of the explanation but not the full explanation for

\footnotetext{
${ }^{8}$ Mace (1991) was the first to run such regressions, using individual-level data and panel-data regressions.

${ }^{9}$ Their paper uses the methodology developed in Asdrubali, Sørensen, and Yosha (1996) applying to U.S. states; see also Becker and Hoffmann (2003). Canova and Ravn (1996) use a different methodology but also reject perfect consumption smoothing.
} 
low international risk sharing. ${ }^{10}$ The impact of non-tradeables depends strongly on the form of utility functions, for example if non-tradeable enters the utility function in an additively separable way consumption of tradeables should be perfectly correlated across countries. In this article, we do not consider tradeables separately from non-tradeables, partly because of the uncertainty about functional forms and about which goods really are non-tradeable, but mainly because our goal is not to test for perfect risk sharing but rather to demonstrate that risk sharing changes with home bias.

A final issue is whether risk sharing is important. Obstfeld (1994a) illustrates that welfare gains from risk sharing in representative agent models are small unless endowment shocks are highly persistent. However, country level output shocks typically are highly persistent and output typically behaves approximately like a random walk in OECD countries. van Wincoop (1994) finds welfare gains equivalent to a permanent increase in consumption of about a couple of percent. ${ }^{11}$ See Tesar (1995) for a more extensive discussion of this issue.

\subsection{Measuring risk sharing}

\section{Year-by-year measures of risk sharing}

Our empirical estimations quantify deviations from perfect income smoothing and perfect consumption smoothing, respectively. Consider a group of countries and the following set of cross-sectional regressions - one for each year $t$ :

$$
\Delta \log \mathrm{GNP}_{i t}-\Delta \log \mathrm{GNP}_{t}=\text { constant }+\beta_{K, t}\left(\Delta \log \mathrm{GDP}_{i t}-\Delta \log \mathrm{GDP}_{t}\right)+\epsilon_{i t} .
$$

$\operatorname{GNP}_{i t}$ and GDP $i t$ are country $i$ 's year $t$ per capita GNP and GDP, respectively, and $\mathrm{GNP}_{t}$ and $\mathrm{GDP}_{t}$ are the year $t$ per capita aggregate GNP and GDP for the

\footnotetext{
${ }^{10}$ Hedging against shocks to endowments of non-tradeables may also be an explanation for home bias see, for example, Pesenti and van Wincoop (2002) who find it unlikely that this mechanism can explain a large fraction of home bias.

${ }^{11}$ Kalemli-Ozcan, Sørensen, and Yosha (2001) derive closed form expressions for welfare gains and find similar magnitudes for most U.S. states in a framework of interstate risk sharing.
} 
group. The coefficient $\beta_{K, t}$ measures the average co-movement of the countries' idiosyncratic GNP growth with their idiosyncratic GDP growth in year $t$ (where "idiosyncratic" refers to the deviation of a country's growth rate of some variable from that of the group). Of course, aggregate fluctuations cannot be eliminated by the sharing of risk, which is why the aggregate component is deducted from the growth rates. Under perfect risk sharing, the left-hand side of equation (2) will be zero which implies $\beta_{K, t}$ will be zero. The smaller the co-movement of idiosyncratic GDP with GNP, the more GNP is buffered against GDP fluctuations and the smaller the estimated value of $\beta_{K, t}$. Since GNP equals GDP plus net factor income from abroad, this regression provides a measure of the extent to which net factor income flows provide income smoothing - the lower $\beta_{K, t}$, the higher is income smoothing within the group in year $t .^{12}$ The estimated series of $\beta_{K, t}$ coefficients measures the evolution of risk sharing over time. Often it is more instructive to look at the equivalent series $1-\beta_{K, t}$ - this series will take the value 1 if risk sharing is perfect and the value 0 if GNP moves one-to-one with output.

In a similar manner, we estimate year-by-year the relation

$$
\Delta \log \mathrm{C}_{i t}-\Delta \log \mathrm{C}_{t}=\text { constant }+\beta_{C, t}\left(\Delta \log \mathrm{GDP}_{i t}-\Delta \log \mathrm{GDP}_{t}\right)+\epsilon_{i t},
$$

where $\mathrm{C}_{i t}$ is country $i$ 's year $t$ per capita final consumption, and $\mathrm{C}_{t}$ is the year $t$ per capita aggregate final consumption for the group. The coefficient $\beta_{C, t}$ measures the average co-movement of the countries' idiosyncratic consumption growth with their idiosyncratic GDP growth in year $t$. The smaller the co-movement, the more consumption is buffered against GDP fluctuations. Therefore, this regression provides a measure of the extent of consumption smoothing.

\footnotetext{
${ }^{12}$ See Asdrubali, Sørensen, and Yosha (1996), Sørensen and Yosha (1998), Mélitz and Zumer (1999), and Becker and Hoffmann (2003).
} 


\section{Does higher foreign asset holdings predict better income and consumption smoothing?}

\subsection{Graphical presentation of cross-sectional evidence}

Figure 2 displays estimates of the series of year-to-year income smoothing measures $1-\beta_{K, t}$ together with the logarithm of equity holdings normalized by GDP. The $\beta_{K, t}$ 's are the estimated coefficients from equation (2) estimated for the sample of OECD countries. More precisely, we display $100 *\left(1-\beta_{K, t}\right)$ which we interpret as the percent income smoothing obtained. The year-by-year risk sharing estimates fluctuate a fair amount so the graph displays the time series of regression coefficients after smoothing the time-variation using a Normal kernel with bandwidth (standard deviation) 2. Risk sharing is negative in the early 1990s. We found that this - somewhat strange - result is due to Finland and Sweden, two countries which were severely affected by economic crises in the early 1990s (banking crisis in Sweden and the aftermath of the Soviet break-up in Finland) and the negative coefficient results from the fact that the sharp drop in GDP in these countries in that period were associated with even sharper drop in GNP. We, therefore, also show the risk sharing coefficients without Finland and Sweden. ${ }^{13}$ The graphs indicate that international risk sharing has been increasing quite steeply through the 1990s. Comparing with the graph for international asset holdings it is highly suggestive that income risk sharing increases when international asset holdings increase.

Figure 3 displays kernel smoothed estimates for year-to-year consumption smoothing; i.e., $100 *\left(1-\beta_{C, t}\right)$, where the $\beta_{C, t}$ 's are the estimated coefficients from equation (3) for the same countries. The graph for asset holdings is the same as in Figure 2. The graphs are similar with or without Finland and Sweden: the large drops in GNP experienced by these countries in the early 1990s seems not

\footnotetext{
${ }^{13}$ The graph leaves the impression that income smoothing might have been negative before the sample we consider but if we extend the graph further back in time we find zero income smoothing.
} 
to have affected consumption significantly. If the banking crisis at the time was expected to be temporary (as it turned out to be) this is what would be expected from permanent income theories of consumption. Overall, this graph confirms the pattern observed in Figure 2 with consumption smoothing increasing after 1995 roughly at the same time as foreign equity holdings start increasing. There is a slight drop of in consumption smoothing at the end of the sample which possibly is due to the world-wide slow-down at the start of the new millennium but more observations would be needed to verify that conjecture.

The results of this section provide highly suggestive time-series evidence that increasing international asset holdings and increasing international risk sharing are manifestations of the same phenomenon. The next subsection explores whether this results holds across the dimensions of the panel data.

\subsection{Panel data regressions: specification}

We estimate panel data regressions of the form:

$$
\Delta \log \mathrm{GNP}_{i t}-\Delta \log \mathrm{GNP}_{t}=\text { constant }+\kappa\left(\Delta \log \mathrm{GDP}_{i t}-\Delta \log \mathrm{GDP}_{t}\right)+\epsilon_{i t}
$$

This regression is similar to that in (2) except that it is now estimated as a panel pooling a number of years. In this specification, suggested by Asdrubali, Sørensen, and Yosha (1996), $1-\kappa$ is a scalar that measures the average amount of income smoothing within the group during the time-period considered. The coefficient $\kappa$ measures the average co-movement of the countries' idiosyncratic GNP-growth with their idiosyncratic GDP-growth over the sample period. ${ }^{14} \mathrm{In}$ this regression, subtracting from each variable the aggregate value is crucial

\footnotetext{
${ }^{14}$ The estimated value of $\kappa$ will approximately be a weighted average of the $\beta_{K, t}$ coefficients as shown by Asdrubali, Sørensen, and Yosha (1996). (Strictly so, if aggregate growth is controlled for using time-specific dummy variables rather than simply subtracting aggregate growth-rates. The inclusion of time-specific dummy variables will give results that are very close to the ones reported and we, therefore, use the slightly simpler setup.)
} 
because aggregate GDP-growth of the group is not insurable. ${ }^{15}$

Mélitz and Zumer (1999) impose structure on $\kappa$ so that $\kappa=\kappa_{0}+\kappa_{1} \gamma_{i}$, where $\gamma_{i}$ is an "interaction" variable that affects the amount of smoothing that country $i$ obtains. The estimated value of $1-\kappa_{0}-\kappa_{1} \gamma_{i}$ then measures the average amount of income smoothing obtained by country $i$ during the time-period in question. We enhance this method by allowing $\kappa$ to change over time, besides including an interaction variable, as follows:

$$
\kappa=\kappa_{0}+\kappa_{1}(t-\bar{t})+\kappa_{2}\left(\mathrm{EHB}_{i t}-\overline{\mathrm{EHB}}_{t}\right)
$$

where

$$
\mathrm{EHB}_{i t} \equiv \text { Equity Home Bias } i t
$$

is our Equity Home Bias measure for country $i$ at time $t . \bar{t}$ is the middle year of the sample period, and $\overline{\mathrm{EHB}}_{t}$ is the (un-weighted) average across countries of $\mathrm{EHB}_{i t}$ at time $t$. The estimated value of $1-\kappa_{0}$ corresponds to the average amount of income smoothing within the group during the period $\bar{t}$. The estimated value of $1-\kappa_{0}-\kappa_{1}(t-\bar{t})-\kappa_{2}\left(\mathrm{EHB}_{i t}-\overline{\mathrm{EHB}}_{t}\right)$ then measures the amount of income smoothing obtained in period $t$ by country $i$ with Equity Home Bias EHBit. We include a time trend in order to guard against the downward trending home bias measure spuriously capturing trend changes in risk sharing that may be caused by other developments in international markets.

The parameter $-\kappa_{1}$ captures the average year-by-year increase in income risk sharing. In this respect, the specification implied by (4) and (5) is a "middleof-the-road" specification between the specification in (2) — where the amount of income smoothing can change freely from period to period - and the specification in (4) where the amount of income smoothing does not change over time. In the specification implied by (4) and (5), the amount of income smoothing is allowed

\footnotetext{
${ }^{15}$ In the regressions in equation (2), subtracting from each variable its time-specific mean, rather than the aggregate value, will not affect the results because each regression is crosssectional and includes a constant.
} 
to change over time with the trend and with Equity Home Bias.

The parameter $-\kappa_{2}$ (which will be negative) captures the extent to which higher than average Equity Home Bias in a country lowers the amount of income risk sharing obtained by country $i$. In fact, $-\kappa_{2}$ can be interpreted as an "exchange ratio" that translates fractions of Equity Home Bias to percentage points of idiosyncratic shocks absorbed via income smoothing. We perform an analogous analysis using Debt Home Bias. In this case $\kappa=\kappa_{0}+\kappa_{1}(t-\bar{t})+\kappa_{2}\left[\mathrm{BHB}_{i t}-\overline{\mathrm{BHB}}_{t}\right]$, where $\mathrm{BHB}_{i t}$ measures Debt Home Bias in country $i$ at time $t$.

We repeat the analysis using foreign asset holdings relative to GDP. In the case where total asset portfolios are small relative to GDP, little risk sharing can be obtained even by internationally well diversified portfolios. In such cases foreign holdings relative to GDP may be the more relevant "home bias" measure for macroeconomic income and consumption smoothing. In the case of equity we let

$$
\kappa=\kappa_{0}+\kappa_{1}(t-\bar{t})+\kappa_{2}\left(\mathrm{E}_{i t}-\overline{\mathrm{E}}_{t}\right)
$$

where

$$
\mathrm{E}_{i t} \equiv \log \left[(\text { foreign equity holdings })_{i t} / \mathrm{GDP}_{i t}\right]
$$

is the ratio of (gross) foreign equity holdings to GDP for country $i$ in year $t$. We use a similar formulation for debt and equity asset holdings and we also explore similar specifications using liabilities. It is possible that one may obtain stronger results if we allow risk sharing to increase proportionally with the total amount of foreign portfolio asset holdings (of equity plus debt holdings) relative to GDP. In this case, we let $\kappa=\kappa_{0}+\kappa_{1}(t-\bar{t})+\kappa_{3}\left[\mathrm{~EB}_{i t}-\overline{\mathrm{EB}}_{t}\right]$ where $\mathrm{EB}_{i t} \equiv$ $\log \left[(\text { foreign equity }+ \text { debt holdings })_{i t} / \mathrm{GDP}_{i t}\right]$ is the log-ratio of foreign debt+equity holdings to GDP for country $i$ in year $t$.

We can include several interaction terms or explore, say, the sum of equity, debt, and foreign direct investment - these extensions are simple permutations of the formulas already described. 
We further estimate the contribution of Equity Home Bias to the amount of consumption risk sharing within the group using regressions of the form:

$$
\Delta \log \mathrm{C}_{i t}-\Delta \log \mathrm{C}_{t}=\text { constant }+\eta\left(\Delta \log \mathrm{GDP}_{i t}-\Delta \log \mathrm{GDP}_{t}\right)+\epsilon_{i t},
$$

where

$$
\eta=\eta_{0}+\eta_{1}(t-\bar{t})+\eta_{2}\left(\mathrm{EHB}_{i t}-\overline{\mathrm{EHB}}_{t}\right) .
$$

In the same manner as the analysis performed for income smoothing, we allow for interaction terms based on the ratio of foreign equity holdings to GDP, Debt Home Bias, the ratio of foreign debt holdings to GDP, etc.

All estimations are performed as two-stage estimations that allow the error variance to differ across countries. The majority of our results displayed are from regressions which include country-fixed effects, although we display select results for the specification without fixed effects to document that the results are robust to this choice.

\section{Panel regressions: results}

Table 5 displays results for income and consumption smoothing as a function of Equity Home Bias for the OECD-sample. We find a near-zero statistically insignificant (at the conventional 5 percent level) coefficient to the time trend. For income smoothing, we find highly significant coefficients to Equity Home Bias. The point estimates are clearly also significant in economic terms: the coefficient estimate for Equity Home Bias is -39 when fixed effects are included, which implies that a country lowering Equity Home Bias by 0.1 will increase income smoothing by about 5 percent. This is a very strong impact of home bias on risk sharing. Considering Debt Home Bias we find a coefficient of -24 with a significant t-statistic. For consumption smoothing, the average estimated amount of risk sharing is much higher at about 50 percent (depending somewhat on the specification) and the impact of Equity Home Bias is estimated at -136 
with very high significance. The point estimate is somewhat high — a large decline in home bias is not likely to lead to more than 100 percent risk sharing (the case where a negative GDP shock leads to a positive change in consumption) as this coefficient might imply and we interpret the coefficient to imply that declining home bias has been associated with significant increasing consumption risk sharing even if the actual value is likely to not be valid for very large changes in home bias. However, we find no association between declining debt home bias and consumption risk sharing.

Table 6 focuses on EU countries and the interpretation of the results are that they measure the amount of risk shared among the countries in the EU. The average amount of income risk sharing in the EU during the sample period is not significantly different from zero but in the EU there is a positive significant trend in income smoothing. However, income risk sharing is not significantly related to either stock or debt home bias. Consumption smoothing among EU countries is lower than among the OECD countries and neither trend nor home bias indices are significantly related to consumption risk sharing. The pattern of aggregate consumption during the late 1990s in the EU is affected by tight fiscal policy for the countries that joined the European Monetary Union (EMU) and we suspect that this lowered risk sharing between EU countries (of which most joined the EMU) during this period.

In Table 7 we display the correlations of the regressors after country-specific means have been subtracted. ${ }^{16}$ We can observe that GNP-growth and GDPgrowth are highly correlated and consumption-growth has a high correlation of 0.71 with GDP-growth. These correlations indicate that income smoothing is low and consumption smoothing far from perfect. The ratios of equity, debt, and foreign direct investment to GDP (interacted with GDP-growth) are highly correlated indicating that it will be challenge to tease out the effect of the in-

\footnotetext{
${ }^{16}$ By the Frisch-Waugh theorem, the estimated coefficients in a regression where the countryspecific means have been subtracted are identical to the coefficient in a regression with countryfixed effects.
} 
dividual components, while liabilities are somewhat less correlated with assets. Equity and foreign direct investment liabilities are highly correlated (0.85) while debt liabilities are slightly less correlated with equity (0.65) and foreign direct investment (0.61).

In Table 8, we ask if the ratio of foreign asset holdings to GDP predicts income and consumption risk sharing. We find a clear positive effect of higher foreign equity holdings (relative to GDP) on income risk sharing. The estimated coefficients have different orders of magnitude than those found for home bias which reflects that the Home Bias measures have different scales than the ratio of assets to GDP. For equity, the t-statistics for the impact of Equity Home Bias on income risk sharing are similar to those found for Equity Home Bias while for debt the significance is higher than what we found using the Home Bias index. Foreign direct investment is less related to income smoothing although the coefficient is still significant. Using the sum of equity and debt or the sum of all assets results in coefficients and t-values at the same order of magnitude as found for debt.

For consumption smoothing, in the lower panel of Table 8, we find the largest impact on risk sharing from equity holdings although the result that higher asset holdings lead to more risk sharing is quite robust: only debt holdings are not significant for consumption smoothing.

In Table 9 we perform regressions of the same for as those of Table 8 using liability data. For income smoothing risk sharing we get larger and more significant coefficients using the sum of either equity and debt or the sum of all three components while all liability components are insignificant for consumption smoothing except for foreign direct investment.

We, next, examine if the results are sensitive to the inclusion of country-fixed effects. The difference between estimates with or without country fixed effects has a simple interpretation. Because the inclusion of country-fixed effects is equivalent to removing the country-level average over the sample of all variables, 
the regressions with country fixed effects are more clearly interpreted as reflecting year-by-year risk sharing while the results from regressions without country-level fixed effects partly reflect "long-run" risk-sharing; i.e. whether countries that over the whole sample period had, say, high GDP growth had GNP growth that was lower than the GDP growth. We do not attempt to more systematically estimate longer-run risk sharing because our short sample is not well suited for such an exercise. Tables 10 and 11 repeats Tables 8 and 9 now without countryfixed effects. The results or these regressions are similar to the earlier ones with country-fixed effects except that the coefficients and significance levels now are lower. This is intuitive since risk sharing is likely to be higher at shorter frequencies - see Becker and Hoffmann (2006) for direct evidence. Overall, the results without fixed effects display the same pattern, equity and debt holdings seem to be relatively more important to income smoothing while it seems that foreign direct investment is more important for consumption risk sharing. Why might this be? Recall that income smoothing relies on international factor income flows (the difference between GDP and GNP) to be less than fully correlated with GDP and consumption could be partly insured against fluctuations in GDP in a fashion that does not necessarily involve international factor income flow if corporations smooth wages across country-borders. Evidence of such behavior is presented in Budd and Slaughter (2000).

Table 12 reports the results of multiple regressions for income risk sharing, respectively. The first row of Table 12 includes interactions for all three asset categories. The point estimates for equity and debt are of similar magnitude and while the estimate for equity is clearly significant the estimate for debt is near significant at the five percent level. Foreign direct investment has a negative coefficient in this specification, the coefficient is even significant but the negative sign is likely the result of high correlation among the regressors. The second row report a similar regression for liabilities. In this regression only debt holdings is near significant at the five percent level. The third row includes both assets 
and liabilities and even if assets and liability holdings are quite highly correlated, the results clearly point to holdings of international assets providing risk sharing with little risk sharing benefits from international liabilities with the possible exception of foreign direct investment although the coefficient to that variable isn't significant at the five percent level. The forth and fifth row further examines if assets dominates liabilities by including only equity assets and liabilities and debt assets and liabilities, respectively. Clearly assets "win out" in both cases. The last row shows the results from a regression including interaction terms for foreign direct investment assets and liabilities and in this regression the liability variable has the stronger influence even though the coefficient is only significant at the ten percent level.

Table 13 shows results for consumption smoothing. Again risk sharing seems to be correlated with foreign equity asset holdings but debt assets has no meaningful impact in the multiple regressions. On the other hand, there is evidence that foreign direct investment liabilities help smooth consumption although this result is not fully robust.

In Table 14, we return to the smaller sample of EU-countries. The results of income risk sharing reveal that risk sharing increases with equity holdings. The results are similar for debt or debt plus equity holdings - likely both are important. However, there is no correlation between higher foreign direct investment and income risk sharing. For consumption smoothing we do not find significant coefficients although the coefficients are robustly positive and of a similar order of magnitude.

Finally, Table 15 examines if any country is an influential observation (statistical outlier) by examining if the results change when countries are left out one-by-one. For brevity, we limit this analysis to the cases of 1) the ratio of foreign equity plus debt assets to GDP and 2) the ratio of foreign direct investment assets to GDP - in both cases with country-fixed effects included.

For case 1), equity plus debt assets, we find that the results for income 
smoothing are very robust, in fact, the lowest t-statistic of 2.97 occurs when the United States is left out and the U.S. observations are based on very large asset holdings and not likely to be "noisy" observations. The estimated impact on consumption risk sharing is less robustly estimated with the t-statistic dipping below the five percent level of significance in several cases - on the other hand, the point estimates are quite robustly in a range between 6 and 11 (although the coefficient is higher at 14, when Ireland is left out).

For case 2), foreign direct investment assets, we find that the results for income smoothing are slightly less robust with the t-statistic dipping below the five percent level of significance when the United States is left out. However, the relation between foreign direct investment assets and consumption smoothing is robust with the lowest t-ratio being a high 3.05 when Norway is dropped.

Overall, the robustness checks indicate that the estimated impact of equity and debt holdings on income smoothing is very robust and the estimated impact of foreign direct investment assets on consumption smoothing is robust.

\section{Concluding remarks}

We find, very robustly, that a high level of foreign portfolio assets is positively related to income risk sharing and that a high level of foreign direct investment assets are correlated with high consumption risk sharing. We find no detectable role for liabilities. Our interpretation is that international asset diversification, including portfolio assets, will lead to increased consumption risk sharing although various forms of shocks to consumption (such as fiscal or monetary policy, consumer sentiment, etc.) makes it harder robustly to detect consumption risk sharing compared to income risk sharing. We also expect countries to diversify ownership by simultaneously increase international assets and liabilities rather than by saving to expand net assets even if countries possibly can obtain more efficient risk sharing by suitable tailoring of asset holdings. 


\section{References}

Adler, Michael and Bernard Dumas (1983), "International Portfolio Choice and Corporation Finance: A Synthesis," Journal of Finance 38, 925-84.

Ahearne, Alan G., William L. Griever and Francis E. Warnock (2004), "Information Costs and Home Bias: An Analysis of U.S. Holdings of Foreign Equities," Journal of International Economics 62, 313-336.

Asdrubali, Pierfederico, Bent E. Sørensen and Oved Yosha (1996), "Channels of Interstate Risk Sharing: United States 1963-90," Quarterly Journal of Economics 111, 1081-110.

Backus, David, Patrick Kehoe and Finn Kydland (1992), "International Real Business Cycles," Journal of Political Economy 100, 745-75.

Baxter, Marianne and Mario Crucini (1993), "Explaining Saving-Investment Correlations," American Economic Review 83, 416-436.

Baxter, Marianne and Urban J. Jermann (1997), "The International Diversification Puzzle is Worse than You Think," American Economic Review 87, 170-180.

Becker, Sascha O. and Mathias Hoffmann (2006), "Intra- and International RiskSharing in the Short Run and the Long Run," European Economic Review $50,777-806$.

Buch, Claudia M., John C. Driscoll and Charlotte Ostergaard (2005), "Cross-Border Diversification in Bank Asset Portfolios," mimeo. Kiel Institute for World Economics, Federal Reserve Board, and Norwegian School of Management.

Budd, John W. and Matthew J. Slaughter (2000), "Are Profits Shared Across Borders? Evidence on International Rent Sharing," NBER Working Paper no. 8014 .

Bulow, Jeremy I. and Kenneth Rogoff (1989), "Sovereign Debt: Is to Forgive to Forget?" American Economic Review 79, 43-50.

Burger, John D. and Francis E. Warnock (2004), "Foreign Participation in LocalCurrency Bond Markets," Federal Reserve Board, International Finance Discussion Papers no. 794.

Cai, Fang and Francis E. Warnock (2004), "International Diversification at Home and Abroad," Federal Reserve Board, International Finance Discussion Papers no. 793 .

Canova, Fabio and Morten Ravn (1996), "International Consumption Risk Sharing," International Economic Review 37, 573-601. 
Cooper, Ian A. and Evi Kaplanis (1994), "Home Bias in Equity Portfolios, Inflation Hedging, and International Capital Market Equilibrium," Review of Financial Studies 7, 45-60.

Coval, Joshua D. and Tobias J. Moskowitz (1999), "Home Bias at Home: Local Equity Preference in Domestic Portfolios," Journal of Finance 54, 20452073.

Dahlquist, Magnus, Lee Pinkowitz, René M. Stulz and Rohan Williamson (2003), "Corporate Governance and the Home Bias," Journal of Financial and Quantitative Analysis 38, 87-110.

Domowitz, Ian, Jack Glen and Ananth Madhavan (2001), "Liquidity, Volatility and Equity Trading Costs across Countries and over Time," International Finance 4, 221-255.

Eaton, Jonathan and Mark Gersovitz (1981), "Debt with Potential Repudiation: Theory and Estimation," Review of Economic Studies 48, 289-309.

Edison, Hali J. and Francis E. Warnock (2004, "U.S. Investors' Emerging Market Equity Portfolios: A Security-Level Analysis," Review of Economics and Statistics 86, 691-704.

French, Kenneth and James Poterba (1991), "Investor Diversification and International Equity Markets," American Economic Review: Papers and Proceedings 81, 222-226.

Gehrig, Thomas (1993), "An Information Based Explanation of the Domestic Bias in International Equity Investment," Scandinavian Journal of Economics 95, 97-109.

Grubel, Herbert L. (1968), "Internationally Diversified Portfolios: Welfare Gains and Capital Flows," American Economic Review 58, 1299-1314.

Heaton, John and Deborah Lucas (1996), "Evaluating the Effects of Incomplete Markets on Risk Sharing and Asset Pricing," Journal of Political Economy 104, 443-487.

Huberman, Gur (2001), "Familiarity Breeds Investment," Review of Financial Studies 14, 659-680.

Jacquillat, Bertrand and Bruno Solnik (1978), "Multinationals Are Poor Tools for Diversification," Journal of Portfolio Management 4, 8-12.

Kalemli-Ozcan, Sebnem, Bent E. Sørensen and Oved Yosha (2001), "Economic Integration, Industrial Specialization and the Asymmetry of Macroeconomic Fluctuations," Journal of International Economics 55, 107-137. 
Kang, Jun-Koo and René M. Stulz (1997), "Why Is There a Home Bias? An Analysis of Foreign Portfolio Equity Ownership in Japan," Journal of Financial Economics 46, 3-28.

Karolyi, G. Andrew and René M. Stulz (2003), "Are Financial Assets Priced Locally or Globally?" in George Constantinides, Milton Harris and René Stulz (eds.), The Handbook of the Economics of Finance, New York: North Holland.

Lane, Philip (2000), "International Diversification and the Irish Economy," Economic and Social Review 31, 37-54.

Lane, Philip (2001), "Do International Investment Income Flows Smooth Income?" Weltwirtschaftliches Archiv 137, 714-736.

Lane, Philip and Gian Maria Milesi-Ferretti (2001), "The External Wealth of Nations: Measures of Foreign Assets and Liabilities for Industrial and Developing Nations," Journal of International Economics 55, 263-294.

Lane, Philip and Gian Maria Milesi-Ferretti (2006), "The External Wealth of Nations Mark II: Revised and Extended Estimates of Foreign Assets and Liabilities, 1970-2004," IMF Working Paper 06/69.

Lewis, Karen (1996), "What Can Explain the Apparent Lack of International Consumption Risk Sharing?" Journal of Political Economy 104, 267-97.

Lewis, Karen (1999), "Trying to Explain Home Bias in Equities and Consumption," Journal of Economic Literature 37, 571-608.

Mace, Barbara, (1991), "Full Insurance in the Presence of Aggregate Uncertainty," Journal of Political Economy 99, 928-956.

Mann, Catherine and Ellen Meade (2002), "Home Bias, Transactions Costs, and Prospects for the Euro: A More Detailed Analysis," Working Paper. Centre of Economic Performance, London School of Economics.

Mélitz, Jacques and Frédéric Zumer (1999), "Interregional and International Risk Sharing and Lessons for EMU," Carnegie-Rochester Conference Series on Public Policy 51, 149-88.

Obstfeld, Maurice (1994a), "Evaluating Risky Consumption Paths: The Role of Intertemporal Substitutability," European Economic Review 38, 1471-86.

Obstfeld, Maurice (1994b), "Are Industrial-Country Consumption Risks Globally Diversified?" in Leonardo Leiderman and Assaf Razin, eds., Capital Mobility: The Impact on Consumption, Investment and Growth, New York: Cambridge University Press. 
Obstfeld, Maurice and Kenneth Rogoff (1996), Foundations of International Macroeconomics, Cambridge, Massachusetts: MIT Press.

Obstfeld, Maurice and Kenneth Rogoff (2000), "The Six Major Puzzles in International Macroeconomics: Is There a Common Cause?" NBER Macroeconomics Annual 2000.

Pesenti, Paolo and Eric van Wincoop (2002), "Can Nontradables Generate Substantial Home Bias?" Journal of Money, Credit and Banking 34, 25-50.

Portes, Richard and Hélène Rey (2005), "The Determinants of Cross Border Equity Flows," Journal of International Economics 65, 269-296,

Rowland, Patrick F. and Linda L. Tesar (1998), "Multinationals and the Gains from International Diversification," NBER Working Paper No. 6733.

Shiller, Robert (1993), Macro Markets: Creating Institutions for Managing Society's Largest Economic Risks, London, U.K.: Oxford University Press.

Sørensen, Bent E. and Oved Yosha (1998), "International Risk Sharing and European Monetary Unification," Journal of International Economics 45, $211-38$.

Standard \& Poor's (2002), Emerging Stock Markets Factbook. New York: Standard \& Poor's.

Stockman, Alan and Linda Tesar (1995), "Tastes and Technology in a Two-Country Model of the Business Cycle: Explaining International Comovements," American Economic Review 85, 168-185.

Strong, Norman and Xinzhong Xu (2003), "Understanding the Equity Home Bias: Evidence from Survey Data," Review of Economics and Statistics 85, 30712.

Tesar, Linda (1995), "Evaluating the Gains from International Risksharing," CarnegieRochester Conference Series on Public Policy 42, 95-143.

Tesar, Linda and Ingrid Werner (1995), "Home Bias and High Turnover," Journal of International Money and Finance 14, 467-92.

Warnock, Francis E. (2002), "Home Bias and High Turnover Reconsidered," Journal of International Money and Finance 21, 795-805.

van Wincoop, E. (1994), "Welfare Gains from International Risk Sharing," Journal of Monetary Economics 34, 175-200. 
Table 1

County-level Foreign Asset and Liability Holdings of Equity, Debt, and

Foreign Direct Investment Relative to GDP

\begin{tabular}{|c|c|c|c|c|c|c|c|c|c|c|c|c|}
\hline \multirow{3}{*}{$\begin{array}{l}\text { Country } \\
\text { Year: }\end{array}$} & \multicolumn{6}{|c|}{ assets } & \multicolumn{6}{|c|}{ liabilities } \\
\hline & \multicolumn{2}{|c|}{ equity } & \multicolumn{2}{|c|}{ debt } & \multicolumn{2}{|c|}{ fdi } & \multicolumn{2}{|c|}{ equity } & \multicolumn{2}{|c|}{ debt } & \multicolumn{2}{|c|}{ fdi } \\
\hline & 1993 & 2003 & 1993 & 2003 & 1993 & 2003 & 1993 & 2003 & 1993 & 2003 & 1993 & 2003 \\
\hline Australia & 0.07 & 0.17 & 0.08 & 0.17 & 0.13 & 0.28 & 0.11 & 0.26 & 0.47 & 0.67 & 0.27 & 0.37 \\
\hline Austria & 0.02 & 0.17 & 0.47 & 1.28 & 0.04 & 0.23 & 0.02 & 0.10 & 0.63 & 1.55 & 0.06 & 0.22 \\
\hline Belgium & 0.27 & 0.47 & 1.46 & 2.48 & 0.28 & 1.01 & 0.04 & 0.09 & 1.51 & 2.36 & 0.43 & 1.15 \\
\hline Canada & 0.18 & 0.36 & 0.18 & 0.25 & 0.17 & 0.37 & 0.08 & 0.22 & 0.66 & 0.62 & 0.19 & 0.32 \\
\hline Denmark & 0.06 & 0.24 & 0.55 & 0.83 & 0.14 & 0.48 & 0.02 & 0.15 & 0.98 & 1.27 & 0.10 & 0.47 \\
\hline Finland & 0.00 & 0.22 & 0.29 & 0.88 & 0.11 & 0.47 & 0.06 & 0.64 & 0.89 & 0.96 & 0.05 & 0.31 \\
\hline France & 0.04 & 0.19 & 0.51 & 1.07 & 0.21 & 0.67 & 0.08 & 0.28 & 0.58 & 1.17 & 0.24 & 0.44 \\
\hline Germany & 0.06 & 0.24 & 0.47 & 1.07 & 0.08 & 0.30 & 0.05 & 0.15 & 0.46 & 1.15 & 0.04 & 0.27 \\
\hline Greece & 0.01 & 0.02 & 0.20 & 0.52 & 0.01 & 0.06 & 0.02 & 0.09 & 0.44 & 1.10 & 0.10 & 0.12 \\
\hline Iceland & 0.00 & 0.32 & 0.04 & 0.38 & 0.02 & 0.16 & 0.00 & 0.06 & 0.67 & 1.51 & 0.02 & 0.11 \\
\hline Ireland & 0.26 & 1.42 & 0.80 & 6.64 & 0.10 & 0.47 & 0.32 & 3.07 & 0.97 & 4.33 & 0.40 & 1.42 \\
\hline Italy & 0.03 & 0.23 & 0.31 & 0.62 & 0.08 & 0.16 & 0.03 & 0.11 & 0.47 & 0.96 & 0.05 & 0.12 \\
\hline Japan & 0.02 & 0.06 & 0.39 & 0.54 & 0.06 & 0.08 & 0.04 & 0.13 & 0.32 & 0.31 & 0.00 & 0.02 \\
\hline Mexico & 0.00 & 0.01 & 0.09 & 0.07 & 0.00 & 0.02 & 0.12 & 0.09 & 0.33 & 0.25 & 0.11 & 0.26 \\
\hline Netherl. & 0.18 & 0.61 & 0.81 & 1.86 & 0.36 & 0.99 & 0.27 & 0.54 & 0.80 & 2.20 & 0.22 & 0.85 \\
\hline N.Zeal. & 0.04 & 0.18 & 0.07 & 0.25 & 0.13 & 0.14 & 0.11 & 0.07 & 0.63 & 0.80 & 0.56 & 0.57 \\
\hline Norway & 0.03 & 0.34 & 0.22 & 0.98 & 0.11 & 0.41 & 0.08 & 0.10 & 0.38 & 1.00 & 0.06 & 0.21 \\
\hline Portugal & 0.02 & 0.08 & 0.29 & 1.35 & 0.02 & 0.24 & 0.03 & 0.24 & 0.41 & 1.72 & 0.15 & 0.40 \\
\hline Spain & 0.01 & 0.10 & 0.28 & 0.71 & 0.05 & 0.34 & 0.07 & 0.21 & 0.40 & 0.98 & 0.16 & 0.38 \\
\hline Sweden & 0.08 & 0.47 & 0.28 & 0.60 & 0.30 & 0.76 & 0.11 & 0.30 & 0.90 & 1.17 & 0.12 & 0.52 \\
\hline Switzerl. & 0.37 & 0.91 & 1.76 & 3.28 & 0.38 & 1.05 & 0.57 & 1.25 & 0.89 & 2.32 & 0.20 & 0.57 \\
\hline Turkey & 0.00 & 0.01 & 0.10 & 0.14 & 0.00 & 0.02 & 0.01 & 0.04 & 0.37 & 0.66 & 0.03 & 0.09 \\
\hline UK & 0.30 & 0.37 & 1.48 & 2.43 & 0.27 & 0.66 & 0.21 & 0.48 & 1.62 & 2.71 & 0.21 & 0.35 \\
\hline US & 0.08 & 0.19 & 0.20 & 0.30 & 0.16 & 0.25 & 0.06 & 0.17 & 0.32 & 0.58 & 0.12 & 0.23 \\
\hline Average & 0.09 & 0.31 & 0.47 & 1.20 & 0.13 & 0.40 & 0.10 & 0.37 & 0.67 & 1.35 & 0.16 & 0.41 \\
\hline
\end{tabular}

Notes. The rows display the value of foreign equity, debt, and foreign direct investment holdings divided by GDP in the same year. The term "debt" refers to debt securities of any maturity while the term "fdi" refers to foreign direct investment. 
Table 2

Stock Market Capitalization and Value of Debt Security Outstanding

\begin{tabular}{|c|c|c|c|c|}
\hline \multirow[t]{2}{*}{ Country } & \multicolumn{2}{|c|}{ Stock Market Capitalization } & \multicolumn{2}{|c|}{ Value of Debt Outstanding } \\
\hline & 1993 & 2003 & 1993 & 2003 \\
\hline Australia & 204.87 & 585.48 & 214.70 & 529.20 \\
\hline Austria & 28.44 & 54.53 & 144.40 & 380.80 \\
\hline Belgium & 78.07 & 173.61 & 337.60 & 551.00 \\
\hline Canada & 326.52 & 893.95 & 622.20 & 999.10 \\
\hline Denmark & 41.79 & 121.62 & 266.70 & 439.60 \\
\hline Finland & 23.56 & 170.28 & 102.40 & 179.60 \\
\hline France & 456.11 & 1355.64 & 1190.00 & 2584.90 \\
\hline Germany & 463.48 & 1079.03 & 1417.30 & 3411.40 \\
\hline Greece & 12.32 & 106.85 & 74.70 & 239.20 \\
\hline Iceland & .. & 9.29 & 4.10 & 29.70 \\
\hline Ireland & & 85.07 & 38.80 & 281.20 \\
\hline Italy & 136.15 & 614.84 & 1234.70 & 2458.80 \\
\hline Japan & 2999.76 & 3040.67 & 4033.20 & 7937.80 \\
\hline Mexico & 200.67 & 122.53 & 108.80 & 207.80 \\
\hline Netherlands & 181.88 & 488.65 & 361.80 & 1548.50 \\
\hline New Zealand & 25.60 & 33.05 & 24.90 & 34.00 \\
\hline Norway & 27.38 & 94.68 & 70.30 & 160.70 \\
\hline Portugal & 12.42 & 58.29 & 44.90 & 176.00 \\
\hline Spain & 119.26 & 726.24 & 290.40 & 904.60 \\
\hline Switzerland & 107.38 & 289.88 & 267.00 & 403.70 \\
\hline Sweden & 271.71 & 726.95 & 171.50 & 239.90 \\
\hline Turkey & 37.50 & 68.38 & 32.00 & 166.20 \\
\hline UK & 1151.65 & 2460.06 & 601.60 & 2128.60 \\
\hline US & 5136.20 & 14266.27 & 9406.20 & 20408.30 \\
\hline $\begin{array}{l}\text { Share of world } \\
\text { capitalization (\%): } \\
\text { Above countries }\end{array}$ & 85.92 & 86.26 & 94.55 & 0152 \\
\hline
\end{tabular}

Notes. Billions of U.S. dollar, end-of-year levels. The Stock Market Capitalization is from Global Stock Markets Factbook 2003, 2004 and 2005 by Standard $\&$ Poor's. Stock market capitalization of the world is the sum of all stock market capitalizations listed in this source. "Debt outstanding" is the sum of domestic debt security outstanding of the country and the international debt security outstanding issued by this country from the BIS. The world number for bonds outstanding is calculated as the sum of bonds outstanding for all countries listed by the BIS. "Share of world capitalization" is the sum of stock market capitalization (or value of debt outstanding) of the above countries divided by stock market capitalization (or value of debt outstanding) of the world. 
Table 3

Equity Home Bias 1993 and 2003

\begin{tabular}{|c|c|c|c|c|c|c|c|}
\hline \multirow[t]{2}{*}{ Country } & \multicolumn{2}{|c|}{$\begin{array}{l}\text { (1) Foreign Equity } \\
\text { in Portfolio (\%) }\end{array}$} & \multicolumn{2}{|c|}{$\begin{array}{l}\text { (2) Domestic } \\
\text { Market Share } \\
\text { of World (\%) }\end{array}$} & \multicolumn{3}{|c|}{ (3) Equity Home Bias } \\
\hline & 1993 & 2003 & 1993 & 2003 & 1993 & 2003 & Diff. \\
\hline Australia & 11.26 & 17.20 & 1.46 & 1.83 & 0.89 & 0.82 & -0.06 \\
\hline Austria & 13.03 & 61.14 & 0.20 & 0.17 & 0.87 & 0.39 & -0.48 \\
\hline Belgium & 45.94 & 50.16 & 0.56 & 0.54 & 0.54 & 0.50 & -0.04 \\
\hline Canada & 26.00 & 30.27 & 2.33 & 2.79 & 0.73 & 0.69 & -0.05 \\
\hline Denmark & 17.14 & 36.58 & 0.30 & 0.38 & 0.83 & 0.63 & -0.20 \\
\hline Finland & 1.66 & 35.02 & 0.17 & 0.53 & 0.98 & 0.65 & -0.34 \\
\hline France & 12.86 & 28.15 & 3.25 & 4.23 & 0.87 & 0.71 & -0.16 \\
\hline Germany & 23.75 & 44.70 & 3.31 & 3.37 & 0.75 & 0.54 & -0.22 \\
\hline Greece & 4.27 & 4.30 & 0.09 & 0.33 & 0.96 & 0.96 & 0.00 \\
\hline Italy & 21.25 & 41.84 & 0.97 & 1.92 & 0.79 & 0.57 & -0.21 \\
\hline Japan & 3.59 & 9.97 & 21.40 & 9.49 & 0.95 & 0.89 & -0.06 \\
\hline Mexico & 1.16 & 11.45 & 1.43 & 0.38 & 0.99 & 0.89 & -0.10 \\
\hline Netherlands & 40.00 & 62.01 & 1.30 & 1.53 & 0.59 & 0.37 & -0.22 \\
\hline New Zealand & 7.10 & 35.10 & 0.18 & 0.10 & 0.93 & 0.65 & -0.28 \\
\hline Norway & 16.70 & 51.45 & 0.20 & 0.30 & 0.83 & 0.48 & -0.35 \\
\hline Portugal & 14.20 & 31.98 & 0.09 & 0.18 & 0.86 & 0.68 & -0.18 \\
\hline Spain & 6.31 & 13.97 & 0.85 & 2.27 & 0.94 & 0.86 & -0.08 \\
\hline Switzerland & 14.94 & 41.60 & 0.77 & 0.91 & 0.85 & 0.58 & -0.27 \\
\hline Sweden & 40.13 & 47.52 & 1.94 & 2.27 & 0.59 & 0.51 & -0.08 \\
\hline Turkey & 1.74 & 2.37 & 0.27 & 0.21 & 0.98 & 0.98 & -0.01 \\
\hline UK & 23.16 & 29.51 & 8.22 & 7.68 & 0.75 & 0.68 & -0.07 \\
\hline US & 10.25 & 14.32 & 36.64 & 44.54 & 0.84 & 0.74 & -0.10 \\
\hline Average & 16.20 & 31.85 & 3.91 & 3.91 & 0.83 & 0.67 & -0.16 \\
\hline
\end{tabular}

Notes. Equity Home Bias in column (3) = [1-column (1)]/[1-column (2)]. Column $(1)=$ total foreign equity held by country / country's total equity portfolio, where the total equity portfolio of a country = stock market capitalization + foreign equity held - amount of country's equity held by foreigners. Column $(2)=$ stock market capitalization of country/ stock market capitalization of the world. Data sources: foreign equity holdings and domestic equity held by foreigners are from Lane and Milesi-Ferretti (2006); stock market capitalizations are from the Standard \& Poor's Global Stock Markets Factbook 2003, 2004 and 2005. 
Table 4

Debt Security Home Bias 1993 and 2003

\begin{tabular}{|c|c|c|c|c|c|c|c|}
\hline \multirow[t]{2}{*}{ Country } & \multicolumn{2}{|c|}{$\begin{array}{l}\text { (1) Foreign Debt } \\
\text { Security in } \\
\text { Portfolio (\%) }\end{array}$} & \multicolumn{2}{|c|}{$\begin{array}{l}\text { (2) Domestic } \\
\text { Market Share } \\
\text { of World }(\%)\end{array}$} & \multicolumn{3}{|c|}{$\begin{array}{l}\text { (3) Debt Security } \\
\text { Home Bias }\end{array}$} \\
\hline & 1993 & 2003 & 1993 & 2003 & 1993 & 2003 & Diff. \\
\hline Australia & 14.68 & 23.73 & 0.96 & 1.04 & 0.85 & 0.76 & -0.09 \\
\hline Austria & 47.25 & 61.79 & 0.65 & 0.75 & 0.52 & 0.38 & -0.15 \\
\hline Belgium & 50.33 & 63.11 & 1.52 & 1.09 & 0.49 & 0.36 & -0.13 \\
\hline Canada & 17.63 & 23.02 & 2.79 & 1.97 & 0.82 & 0.77 & -0.05 \\
\hline Denmark & 24.86 & 31.33 & 1.20 & 0.87 & 0.75 & 0.68 & -0.06 \\
\hline Finland & 31.28 & 57.29 & 0.46 & 0.35 & 0.69 & 0.43 & -0.26 \\
\hline France & 38.72 & 51.12 & 5.34 & 5.10 & 0.59 & 0.46 & -0.13 \\
\hline Germany & 40.57 & 55.52 & 6.36 & 6.73 & 0.57 & 0.40 & -0.16 \\
\hline Greece & 23.83 & 33.95 & 0.34 & 0.47 & 0.76 & 0.66 & -0.10 \\
\hline Iceland & 7.52 & 17.09 & 0.02 & 0.06 & 0.92 & 0.83 & -0.10 \\
\hline Ireland & 63.50 & 93.81 & 0.17 & 0.55 & 0.36 & 0.06 & -0.31 \\
\hline Italy & 20.50 & 30.48 & 5.54 & 4.85 & 0.78 & 0.68 & -0.10 \\
\hline Japan & 31.30 & 22.82 & 18.11 & 15.66 & 0.62 & 0.73 & 0.11 \\
\hline Mexico & 38.10 & 23.01 & 0.49 & 0.41 & 0.62 & 0.77 & 0.15 \\
\hline Netherlands & 54.79 & 63.04 & 1.62 & 3.05 & 0.44 & 0.35 & -0.09 \\
\hline New Zealand & 16.63 & 46.30 & 0.11 & 0.07 & 0.83 & 0.54 & -0.30 \\
\hline Norway & 33.93 & 69.55 & 0.32 & 0.32 & 0.66 & 0.30 & -0.36 \\
\hline Portugal & 38.55 & 61.17 & 0.20 & 0.35 & 0.61 & 0.39 & -0.23 \\
\hline Spain & 34.61 & 47.96 & 1.30 & 1.78 & 0.65 & 0.51 & -0.14 \\
\hline Switzerland & 22.05 & 39.39 & 1.20 & 0.80 & 0.78 & 0.60 & -0.17 \\
\hline Sweden & 71.43 & 82.59 & 0.77 & 0.47 & 0.28 & 0.17 & -0.11 \\
\hline Turkey & 44.52 & 19.08 & 0.14 & 0.33 & 0.55 & 0.81 & 0.25 \\
\hline UK & 77.19 & 84.13 & 2.70 & 4.20 & 0.21 & 0.12 & -0.08 \\
\hline US & 12.55 & 16.07 & 42.23 & 40.25 & 0.78 & 0.73 & -0.05 \\
\hline Average & 35.68 & 46.56 & 3.94 & 3.81 & 0.63 & 0.52 & -0.11 \\
\hline
\end{tabular}

Notes. Debt Security Home Bias in column $(3)=1$-column $(1) /[1-$ column (2)]. Column $(1)=$ total foreign debt security held by country / country's total debt security portfolio, where the total debt security portfolio of a country $=$ domestic debt security outstanding + total foreign debt security assets held. Column (2) = debt market capitalization of country/ debt market capitalization of the world. Data sources: foreign debt holdings of a country and the country's debt held by foreigners are from Lane and Milesi-Ferretti (2006); domestic and international debt security outstanding and world debt market capitalization (debt security portfolio of the world) are from the BIS;. 
Table 5

Risk Sharing and Equity and Debt Security Home Bias: OECD 1993-2003

\begin{tabular}{lcccc}
\hline \multirow{2}{*}{$\begin{array}{l}\text { with country } \\
\text { fixed effects }\end{array}$} & $\begin{array}{c}\text { average } \\
\text { risk sharing }\end{array}$ & trend & $\begin{array}{c}\text { equity } \\
\text { home bias }\end{array}$ & $\begin{array}{c}\text { debt sec. } \\
\text { home bias }\end{array}$ \\
\cline { 3 - 5 } Income & 2 & 0 & -39 & \\
Smoothing & $(1.02)$ & $(0.02)$ & $(4.19)$ & \\
& -1 & 0 & & -24 \\
& $(0.81)$ & $(0.30)$ & & $(2.27)$ \\
\hline \multirow{4}{*}{$\begin{array}{c}\text { Consumption } \\
\text { Smoothing }\end{array}$} & 57 & 2 & -136 & \\
& $(15.06)$ & $(2.09)$ & $(5.48)$ & -6 \\
& 43 & 1 & & $(0.22)$ \\
\hline
\end{tabular}

Notes. Country-fixed effects included. The rows in the top half of the table present 100 times $1-\kappa_{0},-\kappa_{1}$ and $-\kappa_{2}$, where the parameters $\kappa_{0}, \kappa_{1}$, and $\kappa_{2}$ are estimated from panel-data regressions for income smoothing of the form $\Delta \log \mathrm{GNP}_{i t}-\Delta \log \mathrm{GNP}_{t}=$ constant $+\kappa\left(\Delta \log \mathrm{GDP}_{i t}-\Delta \log \mathrm{GDP}_{t}\right)+\epsilon_{i t}$ where $\kappa=\kappa_{0}+\kappa_{1}(t-\bar{t})+$ either $\kappa_{2}\left[\left(\mathrm{EHB}_{i t}\right)-\left(\overline{\mathrm{EHB}}_{t}\right)\right], \mathrm{EHB}_{i t}$ is the period $t$ equity home bias index of country $i$, and $\overline{\mathrm{EHB}}_{t}$ is the (un-weighted) average across countries of $\mathrm{EHB}_{i t}$; or $\kappa_{2}\left[\left(\mathrm{BHB}_{i t}\right)-\left(\overline{\mathrm{BHB}}_{t}\right)\right], \mathrm{BHB}_{i t}$ is the period $t$ debt security home bias index of country $i$, and $\overline{\mathrm{BHB}}_{t}$ is the (un-weighted) average across countries of $\mathrm{BHB}_{i t}$.

The lower half of the table presents the parameters from panel-data regressions for consumption smoothing of the form similar as above and replacing the dependent variable with $\left(\Delta \log \mathrm{C}_{i t}-\Delta \log \mathrm{C}_{t}\right)$. See the text for further details.

The countries included in the sample are Australia, Austria, Belgium, Canada, Denmark, Finland, France, Germany, Greece, Italy, Japan, Mexico, Netherlands, New Zealand Norway, Portugal, Spain, Sweden, Switzerland, Turkey, United Kingdom, and United States. Numbers in parentheses are t-values. 
Table 6

Risk Sharing and Equity and Debt Security Home Bias: EU 1993-2003

\begin{tabular}{lcccc}
\hline \multirow{2}{*}{$\begin{array}{l}\text { with country } \\
\text { fixed effects }\end{array}$} & $\begin{array}{c}\text { average } \\
\text { risk sharing }\end{array}$ & trend & $\begin{array}{c}\text { equity } \\
\text { home bias }\end{array}$ & $\begin{array}{c}\text { debt sec. } \\
\text { home bias }\end{array}$ \\
\cline { 3 - 5 } Income & 1 & 4 & -21 & \\
Smoothing & $(0.33)$ & $(3.46)$ & $(0.75)$ & \\
& 1 & 3 & & -13 \\
& $(0.14)$ & $(3.23)$ & & $(0.41)$ \\
\hline \multirow{3}{*}{$\begin{array}{c}\text { Consumption } \\
\text { Smoothing }\end{array}$} & 27 & 0 & 37 & \\
& $(4.13)$ & $(0.24)$ & $(0.83)$ & \\
& 29 & 0 & & $(0.30)$ \\
\hline
\end{tabular}

Notes. Country-fixed effects included. The rows in the top half of the table present 100 times $1-\kappa_{0},-\kappa_{1}$ and $-\kappa_{2}$, where the parameters $\kappa_{0}, \kappa_{1}$, and $\kappa_{2}$ are estimated from panel-data regressions for income smoothing of the form $\Delta \log \mathrm{GNP}_{i t}-\Delta \log \mathrm{GNP}_{t}=$ constant $+\kappa\left(\Delta \log \mathrm{GDP}_{i t}-\Delta \log \mathrm{GDP}_{t}\right)+\epsilon_{i t}$ where $\kappa=\kappa_{0}+\kappa_{1}(t-\bar{t})+$ either $\kappa_{2}\left[\left(\mathrm{EHB}_{i t}\right)-\left(\overline{\mathrm{EHB}}_{t}\right)\right], \mathrm{EHB}_{i t}$ is the period $t$ equity home bias index of country $i$, and $\overline{\mathrm{EHB}}_{t}$ is the (un-weighted) average across countries of $\mathrm{EHB}_{i t}$; or $\kappa_{2}\left[\left(\mathrm{BHB}_{i t}\right)-\left(\overline{\mathrm{BHB}}_{t}\right)\right], \mathrm{BHB}_{i t}$ is the period $t$ debt security home bias index of country $i$, and $\overline{\mathrm{BHB}}_{t}$ is the (un-weighted) average across countries of $\mathrm{BHB}_{i t}$.

The lower half of the table presents the parameters from panel-data regressions for consumption smoothing of the form similar as above and replacing the dependent variable with $\left(\Delta \log \mathrm{C}_{i t}-\Delta \log \mathrm{C}_{t}\right)$. See the text for further details.

The countries included in the sample are Austria, Belgium, Denmark, Finland, France, Germany, Greece, Italy, Netherlands, Portugal, Spain, Sweden, and United Kingdom. Numbers in parentheses are t-values. 
Table 7

Correlation Matrix of GNP, Consumption, GDP Growth Rates and Foreign

Asset, Liability Ratios Interacted with GDP Growth: OECD 1993-2003

\begin{tabular}{|c|c|c|c|c|c|c|c|c|c|}
\hline & gnp & con & gdp & & assets & & & bilitie & \\
\hline & growth & growth & growth & equity & debt & fdi & equity & debt & fdi \\
\hline gnp growth & 1.00 & 0.71 & 0.95 & -0.69 & -0.61 & -0.66 & -0.58 & -0.38 & -0.55 \\
\hline con growth & & 1.00 & 0.71 & -0.60 & -0.50 & -0.62 & -0.45 & -0.24 & -0.48 \\
\hline gdp growth & & & 1.00 & -0.64 & -0.56 & -0.64 & -0.55 & -0.32 & -0.51 \\
\hline equity asset & & & & 1.00 & 0.81 & 0.89 & 0.77 & 0.65 & 0.80 \\
\hline debt asset & & & & & 1.00 & 0.76 & 0.82 & 0.76 & 0.69 \\
\hline fdi asset & & & & & & 1.00 & 0.79 & 0.57 & 0.78 \\
\hline equity liabil & & & & & & & 1.00 & 0.65 & 0.84 \\
\hline debt liability & & & & & & & & 1.00 & 0.61 \\
\hline fdi liability & & & & & & & & & 1.00 \\
\hline
\end{tabular}

Notes. The term "con growth" stands for consumption growth rate. The term "gnp growth" represents the data series of $\left(\Delta \log \mathrm{GNP}_{i t}-\Delta \log \mathrm{GNP}_{t}\right)$, where GNP $i t$ is country $i$ 's year $t$ per capita GNP, and GNP $_{t}$ is the year $t$ per capita aggregate GNP for the group. The series "con growth" and "gdp growth" are defined similarly.

The term "equity asset" refers to the data series of $\left[\left(\mathrm{E}_{i t}-\overline{\mathrm{E}}_{t}\right) *\left(\Delta \log \mathrm{GDP}_{i t}-\right.\right.$ $\left.\left.\Delta \log \operatorname{GDP}_{t}\right)\right]$, where $\mathrm{E}_{i t}$ is the period $t$ natural logarithm of the ratio of foreign equity owned to GDP for country $i$, and $\overline{\mathrm{E}}_{t}$ is the (un-weighted) average across countries of $\mathrm{E}_{i t}$. " debt asset," "fdi asset," and liabilities are defined similarly.

Country-fixed effects included. The countries included in the sample are Australia, Austria, Belgium, Canada, Denmark, Finland, France, Germany, Greece, Iceland, Ireland, Italy, Japan, Mexico, Netherlands, New Zealand Norway, Portugal, Spain, Sweden, Switzerland, Turkey, United Kingdom, and United States. 
Table 8

Risk Sharing and Foreign Asset Holdings Relative to GDP: OECD 1993-2003

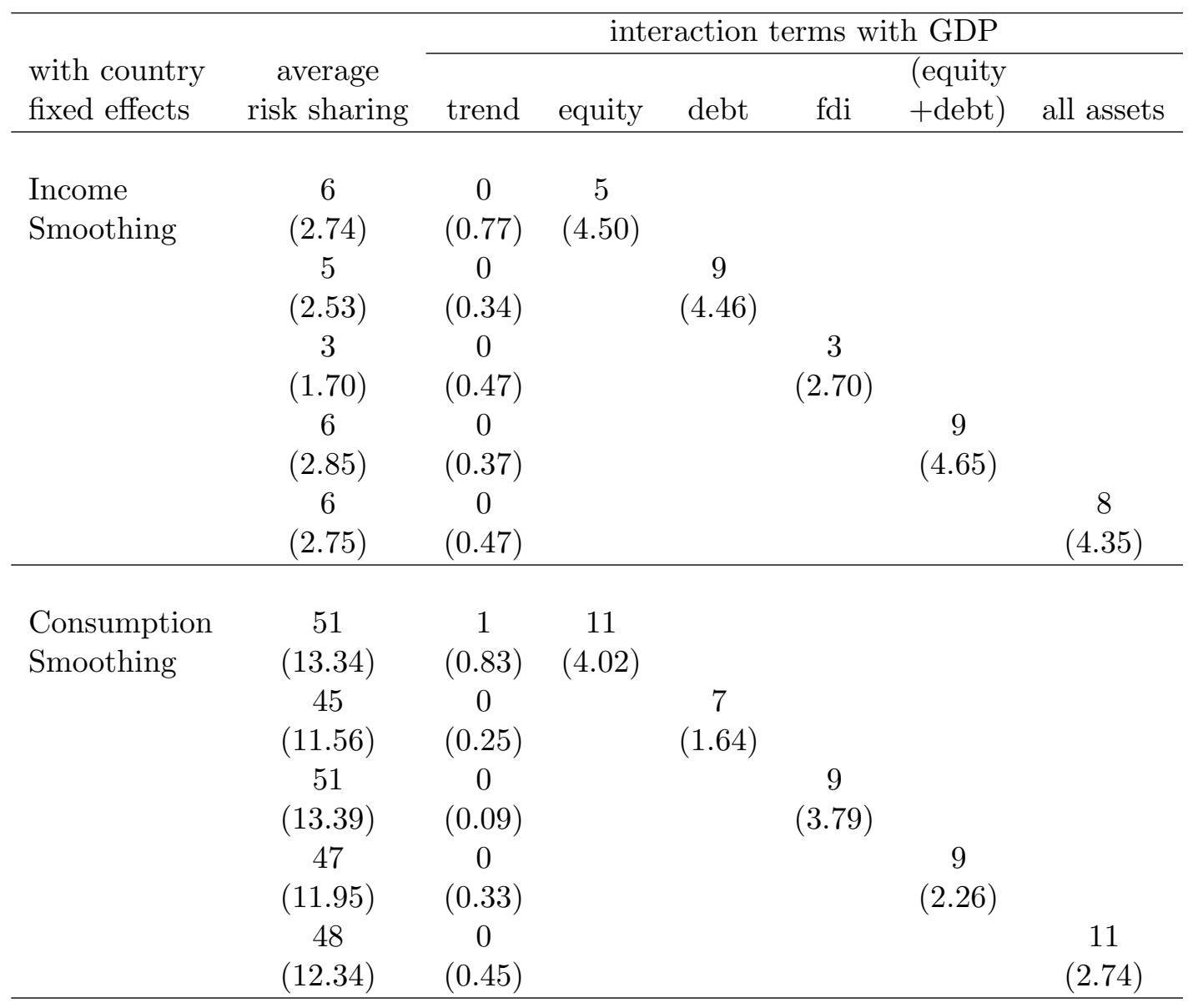

Notes. Country-fixed effects included. Rows in the top half of the table present 100 times $1-\kappa_{0},-\kappa_{1}$ and $-\kappa_{2}$, where the $\kappa_{0}, \kappa_{1}$, and $\kappa_{2}$ are estimated from panel-data regressions of the form $\Delta \log \mathrm{GNP}_{i t}-\Delta \log \mathrm{GNP}_{t}=$ constant + $\kappa\left(\Delta \log \mathrm{GDP}_{i t}-\Delta \log \mathrm{GDP}_{t}\right)+\epsilon_{i t}$ where $\kappa=\kappa_{0}+\kappa_{1}(t-\bar{t})+\kappa_{2}$ times "equity," "debt," "fdi," "equity+debt," or "all assets." For example, "equity" refers [( $\mathrm{E}_{i t}$ $\left.\overline{\mathrm{E}}_{t}\right)$ ], where $\mathrm{E}_{i t}$ is the period $t$ natural logarithm of the ratio of foreign equity assets to GDP for country $i$, and $\overline{\mathrm{E}}_{t}$ is the average of $\mathrm{E}_{i t}$. The other asset categories take the same format as equity. The term "debt" denotes foreign debt security assets and the term "fdi" denotes foreign direct investment holdings. "All assets" is the sum of equity, debt, and fdi. Numbers in parentheses are t-values. The lower half of the table presents the parameters from panel-data regressions for consumption smoothing of the form similar to those of the upper panel with the dependent variable $\left(\Delta \log \mathrm{C}_{i t}-\Delta \log \mathrm{C}_{t}\right)$. See the text for further details. 
Table 9

Risk Sharing and Foreign Liability Holdings Relative to GDP: OECD

1993-2003

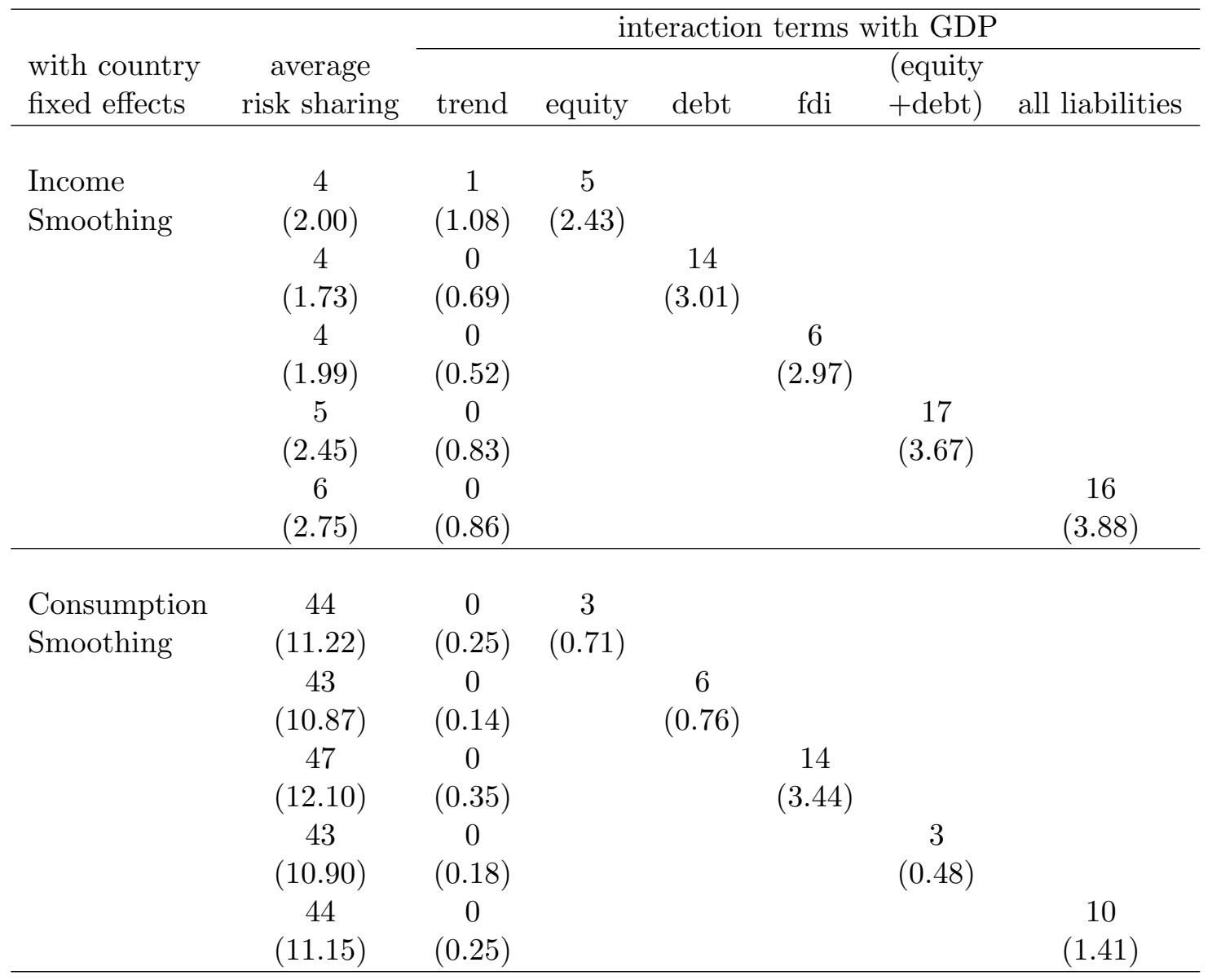

Notes. Country-fixed effects included. Rows in the top half of the table present 100 times $1-\kappa_{0},-\kappa_{1}$ and $-\kappa_{2}$, where the $\kappa_{0}, \kappa_{1}$, and $\kappa_{2}$ are estimated from panel-data regressions of the form $\Delta \log \mathrm{GNP}_{i t}-\Delta \log \mathrm{GNP}_{t}=$ constant + $\kappa\left(\Delta \log \mathrm{GDP}_{i t}-\Delta \log \mathrm{GDP}_{t}\right)+\epsilon_{i t}$ where $\kappa=\kappa_{0}+\kappa_{1}(t-\bar{t})+\kappa_{2}$ times "equity," "debt," "fdi," "equity+debt," or "all assets." For example, "equity" refers [( $\mathrm{E}_{i t}-$ $\left.\overline{\mathrm{E}}_{t}\right)$ ], where $\mathrm{E}_{i t}$ is the period $t$ natural logarithm of the ratio of foreign equity liabilities to GDP for country $i$, and $\overline{\mathrm{E}}_{t}$ is the average of $\mathrm{E}_{i t}$. The other liability categories take the same format as equity. The term "debt" denotes foreign debt security liabilities and the term "fdi" denotes foreign direct investment liabilities. "All liabilities" is the sum of equity, debt, and fdi. Numbers in parentheses are t-values. The lower half of the table presents the parameters from panel-data regressions for consumption smoothing of the form similar to those of the upper panel with the dependent variable $\left(\Delta \log \mathrm{C}_{i t}-\Delta \log \mathrm{C}_{t}\right)$. See the text for further details. 
Table 10

Risk Sharing and Foreign Asset Holdings Relative to GDP: OECD 1993-2003

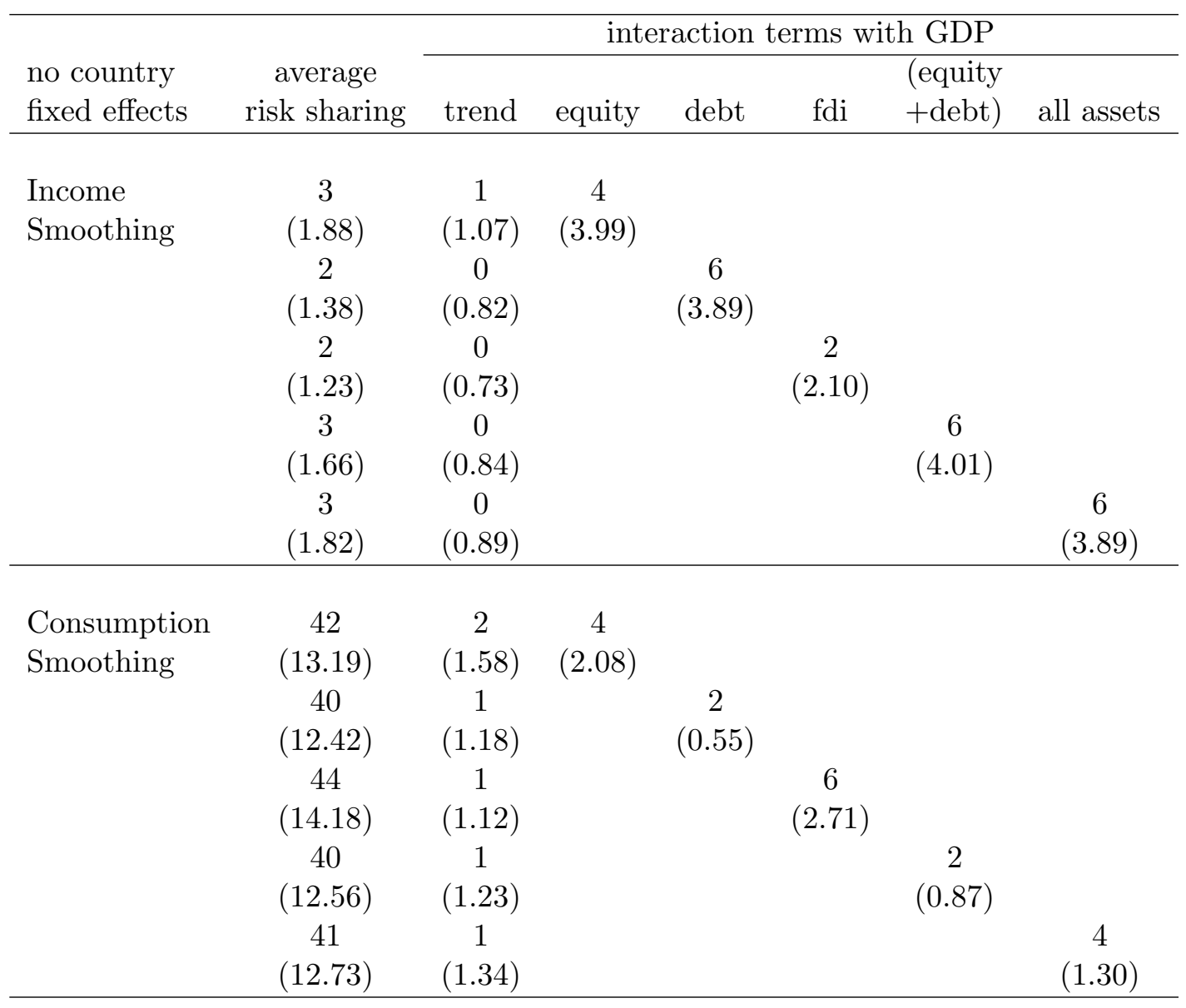

Notes. The table reports the results from regressions of the same form as those presented in Table 8 except country-fixed effects are not included. The values of coefficients are reported in percent. Numbers in parentheses are tvalues.

The countries included in the sample are the same as those in Table 8. They are Australia, Austria, Belgium, Canada, Denmark, Finland, France, Germany, Greece, Iceland, Ireland, Italy, Japan, Mexico, Netherlands, New Zealand Norway, Portugal, Spain, Sweden, Switzerland, Turkey, United Kingdom, and United States. 
Table 11

Risk Sharing and Foreign Liability Holdings Relative to GDP: OECD

$1993-2003$

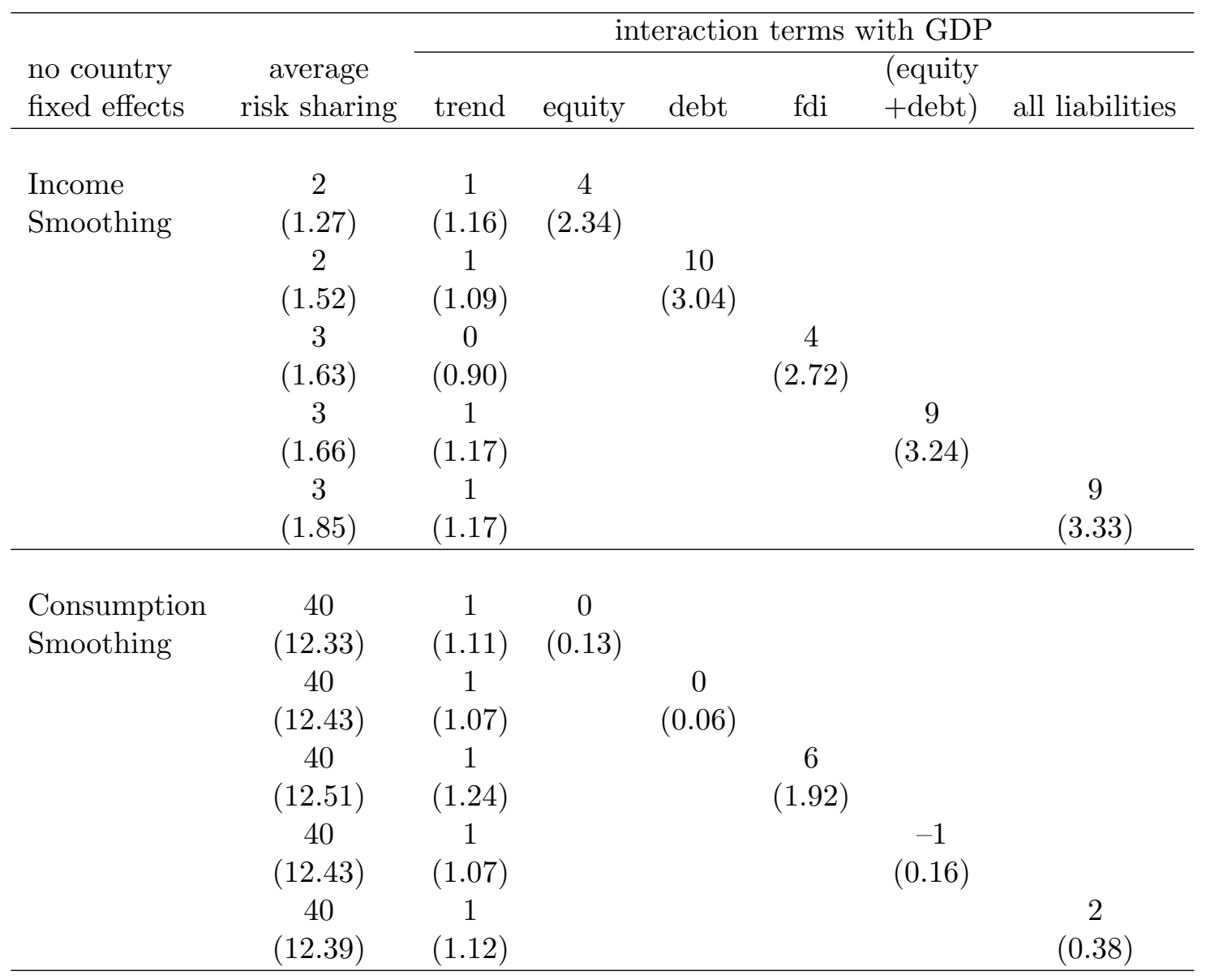

Notes. The table reports the results from regressions of the same form as those presented in Table 9 except country-fixed effects are not included. The values of coefficients are reported in percent. Numbers in parentheses are tvalues.

The countries included in the sample are the same as those in Table 9. They are Australia, Austria, Belgium, Canada, Denmark, Finland, France, Germany, Greece, Iceland, Ireland, Italy, Japan, Mexico, Netherlands, New Zealand Norway, Portugal, Spain, Sweden, Switzerland, Turkey, United Kingdom, and United States. 
Table 12

Income Smoothing and Foreign Asset and Liability Holdings Relative to GDP:

OECD 1993-2003

\begin{tabular}{|c|c|c|c|c|c|c|c|}
\hline \multirow{3}{*}{$\begin{array}{c}\text { average } \\
\text { risk sharing }\end{array}$} & \multicolumn{7}{|c|}{ interaction terms with GDP } \\
\hline & \multirow[b]{2}{*}{ trend } & \multicolumn{3}{|c|}{ assets } & \multicolumn{3}{|c|}{ liabilities } \\
\hline & & equity & debt & fdi & equity & debt & fdi \\
\hline $\begin{array}{c}6 \\
(2.64)\end{array}$ & $\begin{array}{c}1 \\
(1.49)\end{array}$ & $\begin{array}{c}7 \\
(3.34)\end{array}$ & $\begin{array}{c}6 \\
(1.86)\end{array}$ & $\begin{array}{c}-4 \\
(2.71)\end{array}$ & & & \\
\hline $\begin{array}{c}6 \\
(2.62)\end{array}$ & $\begin{array}{c}0 \\
(0.76)\end{array}$ & & & & $\begin{array}{c}3 \\
(1.03)\end{array}$ & $\begin{array}{r}9 \\
(1.62)\end{array}$ & $\begin{array}{c}3 \\
(1.01)\end{array}$ \\
\hline $\begin{array}{c}7 \\
(3.12)\end{array}$ & $\begin{array}{c}1 \\
(1.43)\end{array}$ & $\begin{array}{c}6 \\
(2.71)\end{array}$ & $\begin{array}{c}7 \\
(1.69)\end{array}$ & $\begin{array}{c}-5 \\
(2.75)\end{array}$ & $\begin{array}{c}0 \\
(0.01)\end{array}$ & $\begin{array}{r}-1 \\
(0.22)\end{array}$ & $\begin{array}{c}4 \\
(1.61)\end{array}$ \\
\hline $\begin{array}{c}6 \\
(2.63)\end{array}$ & $\begin{array}{c}0 \\
(0.81)\end{array}$ & $\begin{array}{c}5 \\
(3.59)\end{array}$ & & & $\begin{array}{c}0 \\
(0.06)\end{array}$ & & \\
\hline $\begin{array}{c}5 \\
(2.66)\end{array}$ & $\begin{array}{c}0 \\
(0.44)\end{array}$ & & $\begin{array}{c}8 \\
(3.26)\end{array}$ & & & $\begin{array}{r}5 \\
(0.93)\end{array}$ & \\
\hline $\begin{array}{c}5 \\
(2.25)\end{array}$ & $\begin{array}{c}0 \\
(0.33)\end{array}$ & & & $\begin{array}{c}1 \\
(1.27)\end{array}$ & & & $\begin{array}{c}4 \\
(1.70)\end{array}$ \\
\hline
\end{tabular}

Notes. Country-fixed effects included. The specification of the regressions are similar to those of Tables 8 and 9 except several interaction terms are included. The values of coefficients are reported in percent. Numbers in parentheses are t-values. 
Table 13

Consumption Smoothing and Foreign Asset and Liability Holdings Relative to GDP: OECD 1993-2003

\begin{tabular}{|c|c|c|c|c|c|c|c|}
\hline \multirow{3}{*}{$\begin{array}{l}\text { average } \\
\text { risk sharing }\end{array}$} & \multicolumn{7}{|c|}{ interaction terms with GDP } \\
\hline & \multirow[b]{2}{*}{ trend } & \multicolumn{3}{|c|}{ assets } & \multicolumn{3}{|c|}{ liabilities } \\
\hline & & equity & debt & fdi & equity & debt & fdi \\
\hline $\begin{array}{c}53 \\
(13.79)\end{array}$ & $\begin{array}{c}1 \\
(0.75)\end{array}$ & $\begin{array}{c}11 \\
(2.27)\end{array}$ & $\begin{array}{c}-10 \\
(1.98)\end{array}$ & $\begin{array}{c}4 \\
(1.05)\end{array}$ & & & \\
\hline $\begin{array}{c}46 \\
(12.02)\end{array}$ & $\begin{array}{c}0 \\
(0.05)\end{array}$ & & & & $\begin{array}{c}-7 \\
(1.59)\end{array}$ & $\begin{array}{r}-9 \\
(0.90)\end{array}$ & $\begin{array}{c}21 \\
(3.93)\end{array}$ \\
\hline $\begin{array}{c}55 \\
(14.80)\end{array}$ & $\begin{array}{c}1 \\
(0.56)\end{array}$ & $\begin{array}{c}13 \\
(2.60)\end{array}$ & $\begin{array}{c}7 \\
(0.96)\end{array}$ & $\begin{array}{c}5 \\
(1.08)\end{array}$ & $\begin{array}{c}-20 \\
(4.30)\end{array}$ & $\begin{array}{r}-27 \\
(2.11)\end{array}$ & $\begin{array}{c}12 \\
(1.84)\end{array}$ \\
\hline $\begin{array}{c}52 \\
(13.87)\end{array}$ & $\begin{array}{c}1 \\
(0.67)\end{array}$ & $\begin{array}{c}18 \\
(5.41)\end{array}$ & & & $\begin{array}{c}-16 \\
(3.47)\end{array}$ & & \\
\hline $\begin{array}{c}47 \\
(12.11)\end{array}$ & $\begin{array}{c}0 \\
(0.03)\end{array}$ & & $\begin{array}{c}14 \\
(2.17)\end{array}$ & & & $\begin{array}{r}-19 \\
(1.50)\end{array}$ & \\
\hline $\begin{array}{c}50 \\
(13.12)\end{array}$ & $\begin{array}{c}0 \\
(0.15)\end{array}$ & & & $\begin{array}{c}7 \\
(2.14)\end{array}$ & & & $\begin{array}{c}6 \\
(1.16)\end{array}$ \\
\hline
\end{tabular}

Notes. Country-fixed effects included. The specifications of the regressions are similar to those of Tables 8 and 9 except several interaction terms are included. The values of coefficients are reported in percent. Numbers in parentheses are t-values. 
Table 14

Risk Sharing and Foreign Asset Holdings Relative to GDP: EU 1993-2003

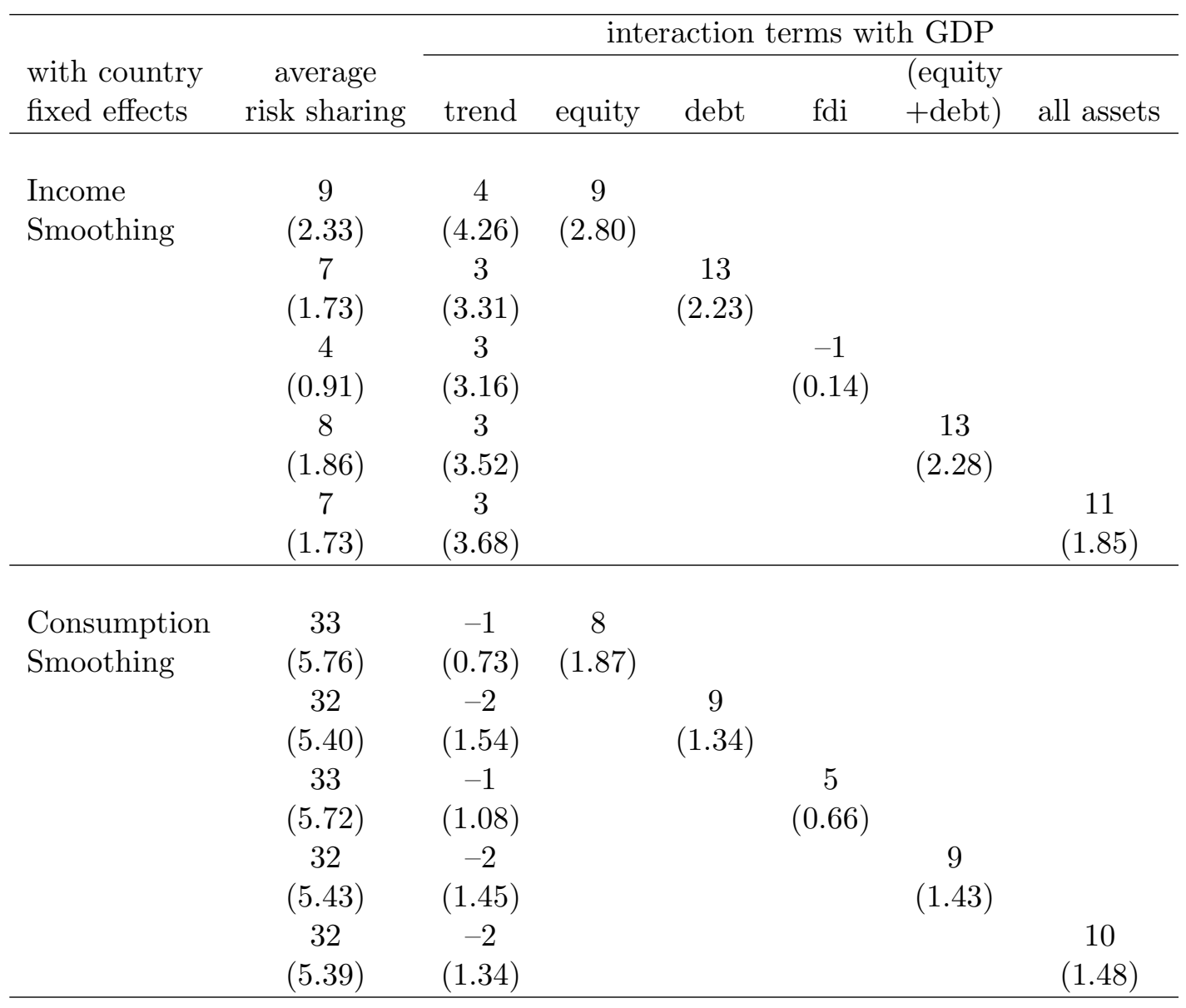

Notes. Country-fixed effects included. The specifications of the regressions are identical to those of Table 8. Countries included are Austria, Belgium, Denmark, Finland, France, Germany, Greece, Ireland, Italy, Netherlands, Portugal, Spain, Sweden, and United Kingdom. The values of coefficients are reported in percent. Numbers in parentheses are t-values. 
Table 15

Risk Sharing and Foreign Equity Plus Debt Assets (FDI Assets) Relative to GDP: Sensitivity Test

\begin{tabular}{|c|c|c|c|c|c|c|c|c|}
\hline \multirow{2}{*}{$\begin{array}{l}\text { Left-out } \\
\text { Country }\end{array}$} & \multicolumn{4}{|c|}{ Income Smoothing } & \multicolumn{4}{|c|}{ Consumption Smoothing } \\
\hline & \multicolumn{2}{|c|}{ equity+debt } & \multicolumn{2}{|r|}{ fdi } & \multicolumn{2}{|c|}{ equity+debt } & \multicolumn{2}{|c|}{ fdi } \\
\hline Australia & 9 & $(4.59)$ & 3 & $(2.81)$ & 10 & $(2.30)$ & 9 & $(3.76)$ \\
\hline Austria & 9 & $(4.71)$ & 3 & $(2.73)$ & 9 & $(2.28)$ & 9 & $(3.78)$ \\
\hline Belgium & 9 & $(4.89)$ & 3 & $(2.79)$ & 6 & $(1.47)$ & 8 & $(3.32)$ \\
\hline Canada & 9 & $(4.79)$ & 3 & $(2.87)$ & 9 & $(2.26)$ & 9 & $(3.66)$ \\
\hline Denmark & 9 & $(4.54)$ & 3 & $(2.60)$ & 9 & $(2.26)$ & 9 & $(3.81)$ \\
\hline Finland & 9 & $(4.83)$ & 3 & $(2.91)$ & 9 & $(2.29)$ & 10 & $(3.93)$ \\
\hline France & 9 & $(4.72)$ & 3 & $(2.70)$ & 9 & $(2.27)$ & 9 & $(3.53)$ \\
\hline Germany & 9 & $(4.66)$ & 3 & $(2.68)$ & 9 & $(2.27)$ & 10 & $(3.82)$ \\
\hline Greece & 9 & $(4.71)$ & 3 & $(2.72)$ & 10 & $(2.34)$ & 10 & $(3.79)$ \\
\hline Iceland & 9 & $(4.73)$ & 3 & $(2.71)$ & 8 & $(1.98)$ & 9 & $(3.76)$ \\
\hline Ireland & 7 & $(3.21)$ & 2 & $(2.44)$ & 14 & $(2.97)$ & 9 & $(3.71)$ \\
\hline Italy & 9 & $(4.69)$ & 3 & $(2.64)$ & 9 & $(2.12)$ & 9 & $(3.76)$ \\
\hline Japan & 10 & $(4.69)$ & 3 & $(2.60)$ & 6 & $(1.32)$ & 8 & $(3.31)$ \\
\hline Mexico & 9 & $(4.72)$ & 2 & $(2.44)$ & 8 & $(2.01)$ & 9 & $(3.52)$ \\
\hline Netherlands & 9 & $(4.67)$ & 3 & $(2.65)$ & 11 & $(2.64)$ & 10 & $(4.17)$ \\
\hline New Zealand & 9 & $(4.65)$ & 3 & $(2.49)$ & 11 & $(2.72)$ & 9 & $(3.57)$ \\
\hline Norway & 9 & $(4.23)$ & 2 & $(1.96)$ & 7 & (1.67) & 8 & $(3.05)$ \\
\hline Portugal & 9 & $(4.55)$ & 3 & $(2.67)$ & 10 & $(2.45)$ & 10 & $(3.84)$ \\
\hline Spain & 9 & $(4.76)$ & 3 & $(2.74)$ & 8 & $(2.08)$ & 9 & $(3.67)$ \\
\hline Sweden & 9 & $(5.01)$ & 3 & $(3.11)$ & 9 & $(2.26)$ & 11 & $(4.30)$ \\
\hline Switzerland & 9 & $(4.67)$ & 3 & $(2.73)$ & 9 & $(2.01)$ & 9 & $(3.69)$ \\
\hline Turkey & 10 & $(3.57)$ & 6 & $(3.21)$ & 7 & $(1.43)$ & 17 & $(3.67)$ \\
\hline UK & 10 & $(4.87)$ & 3 & $(2.77)$ & 10 & $(2.47)$ & 10 & $(3.96)$ \\
\hline US & 6 & $(2.97)$ & 2 & $(1.83)$ & 9 & $(2.37)$ & 9 & $(3.72)$ \\
\hline
\end{tabular}

Notes. Country-fixed effects included. The table reports the results from regressions of the same form as those in Table 8 leaving out one country at a time. Numbers in parentheses are t-values. 
Figure 1: Equity and Debt Security Home Bias Indices in the OECD

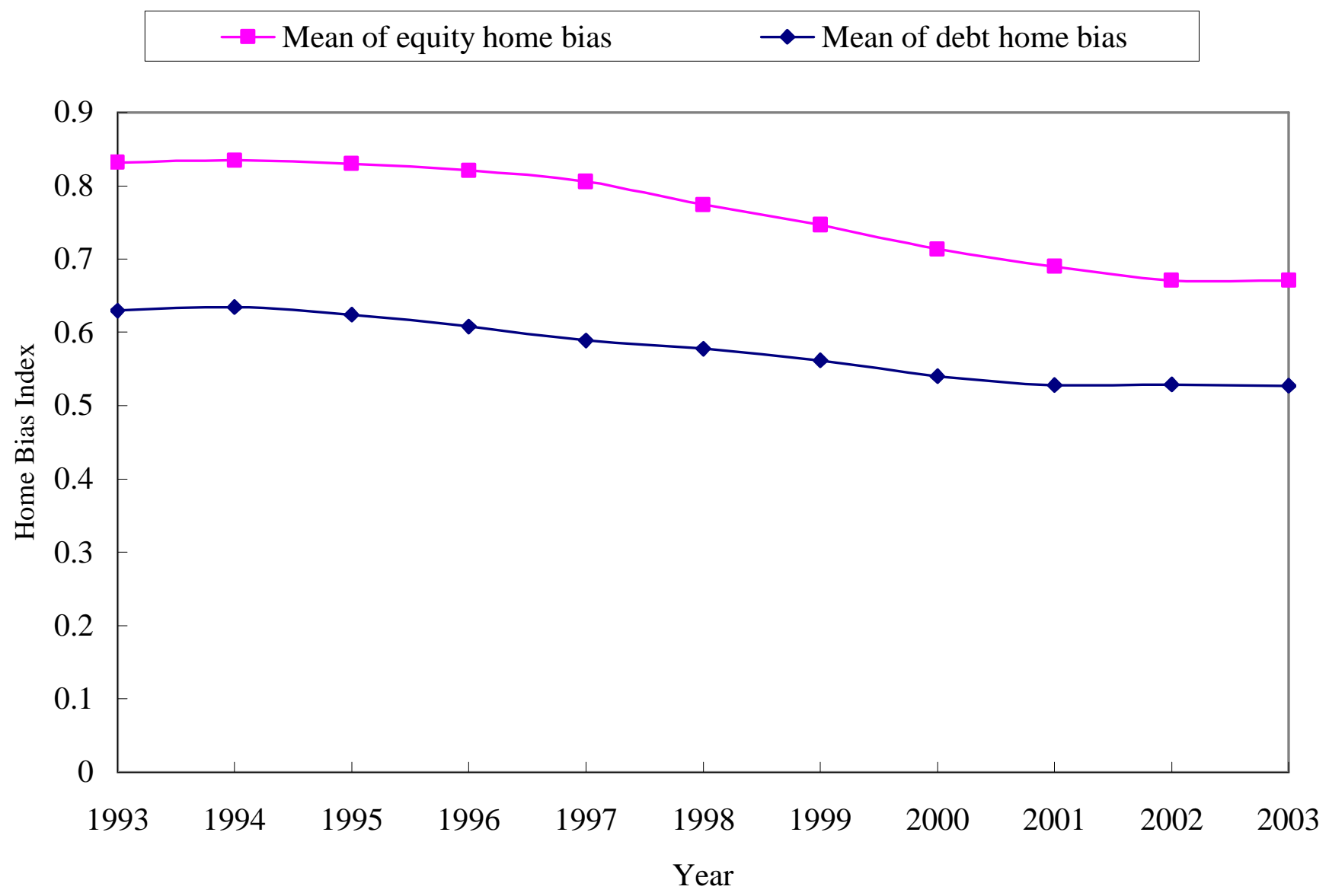

Notes. Mean of equity home bias and mean of debt home bias are the cross-sectional mean for 22 OECD countries. The countries comprise the subset of OECD for which equity home bias index is available (see text). 
Figure 2: Income Risk Sharing and Foreign Asset Holdings in the OECD

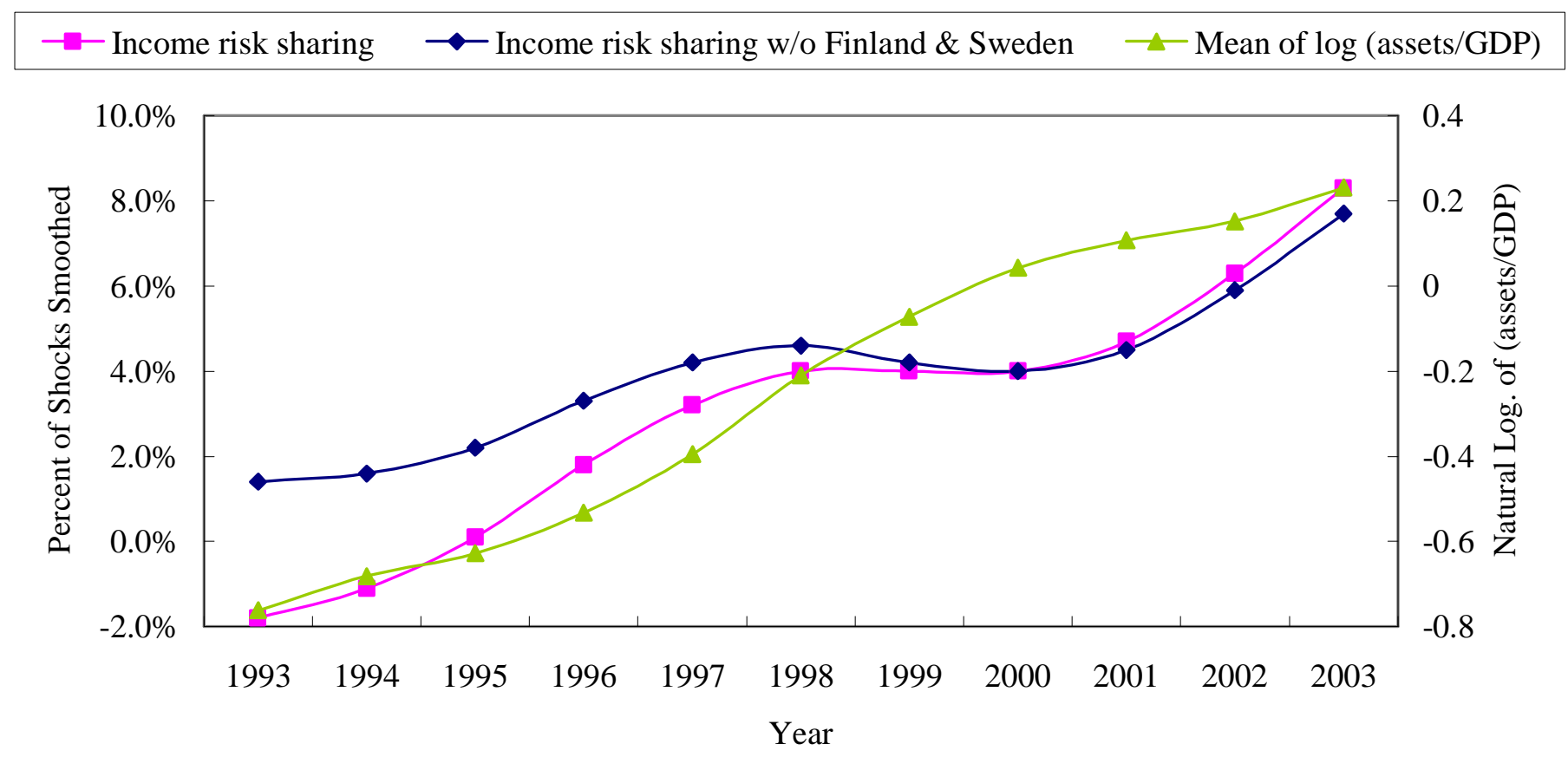

Figure 3: Consumption Risk Sharing and Foreign Asset Holdings in the OECD

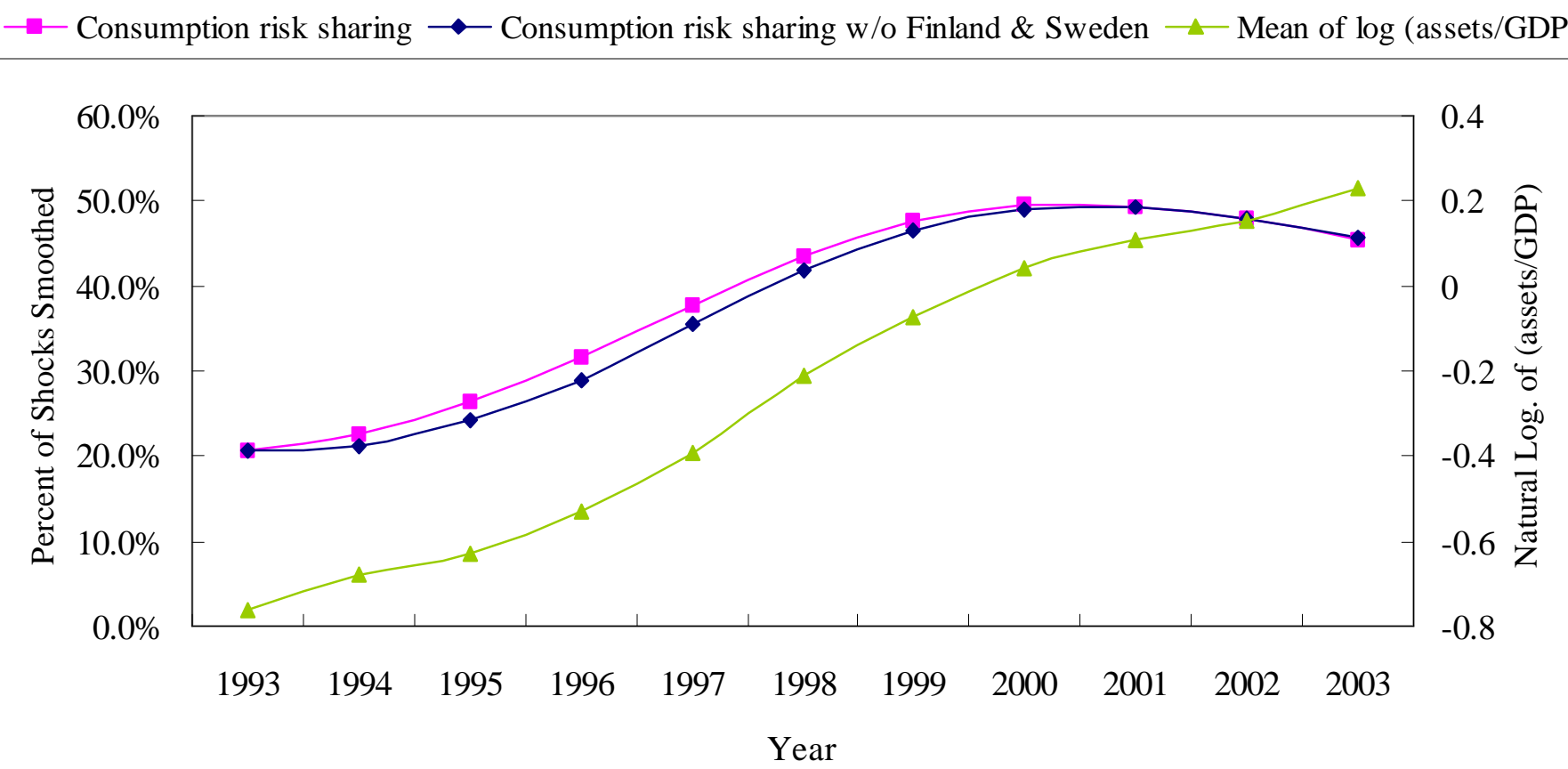

Notes. Mean of log (assets/GDP) is the cross-sectional mean of foreign (equity+debt+FDI) holdings normalized by GDP for 24 OECD countries. The countries comprise the subset of OECD for which data are available (see text). Risk sharing is estimated cross-sectionally year-by-year and is smoothed by using a Normal kernel with bandwidth (standard deviation) equal to 2. 